HID 45 (2018)

\title{
LA MEDIA Y BAJA NOBLEZA CASTELLANA DURANTE LA REGENCIA DE LOS TUTORES DE JUAN II DE CASTILLA, $1407-1418^{1}$
}

\author{
THE MIDDLE AND LOWER CASTILIAN NOBILITY DURING THE \\ REGENCY OF THE TUTORS OF JUAN II OF CASTILE, 1407-1418
}

\section{SANTIAGo GonZÁlez SÁNCHEZ}

IES. Santo Domingo, El Puerto de Santa María

santiago.gonzalez@iessantodomingo.com ORCID: https://orcid.org/0000-0003-1823-3833

RESUMEN: Al lado de la alta nobleza castellana bajomedieval y situada más bajo en la escala social, encontramos a una numerosa nobleza media y baja sin títulos, con frecuencia dependiente de los grandes a los que sirven de apoyo en cualquier tipo de empresas. El presente artículo se centra de manera casi exclusiva en la participación de esta media y baja nobleza castellana en tres ámbitos. El primero, en las actividades militares contra el reino nazarí y en la Corona de Aragón; el segundo, su presencia en las Órdenes militares, y el tercero en el gobierno de ciudades y villas. Tres contextos en los que su participación fue imprescindible para los fines de la monarquía, de la alta nobleza y de los suyos mismos.

PALABRAS ClAVE: Castilla; Juan II; Fernando de Antequera; campañas militares; órdenes militares; bandos; oficios; siglo XV.

ABSTRACT: Together with the high late medieval nobility, we find middle and lower nobles without titles who support high noblemen in the defence of their interests and are under their authority. This article focuses almost exclusively on the participation of this middle and lower Castilian nobility in three fields. The first one, in the military activities against the Nasrid kingdom and in the Aragón Crown; the second, the nobility presence in the military Orders and

Recibido: 10-2-2018; Aceptado: 9-4-2018; Versión definitiva: 23-4-2018.

1. Abreviaturas utilizadas: AAÁ = Archivo del Asocio de Ávila; $\mathrm{ADM}=$ Archivo Ducal de Medinaceli; AGN = Archivo General de Navarra; AGS = Archivo General de Simancas; AHN = Archivo Histórico Nacional; AMCó = Archivo Municipal de Córdoba; AMCRo = Archivo Municipal Ciudad Rodrigo; AMJeF = Archivo Municipal de Jerez de la Frontera; AMLeq = Archivo Municipal de Lequeitio; $\mathrm{AMM}=$ Archivo Municipal de Murcia; $\mathrm{AMSeg}=$ Archivo Municipal de Segura; AN/TT = Archivo Nacional Torre do Tombo; APÁl = Archivo Provincial de Álava; AV = Archivo Vaticano; $\mathrm{AVM}=$ Archivo Villa de Madrid; $\mathrm{CVV}=$ Archivo Casa Bailío; $\mathrm{RAH}=$ Real Academia de la Historia .

Copyright: (C) Editorial Universidad de Sevilla. Este es un artículo de acceso abierto distribuido bajo los términos de la licencia de uso y distribución Creative Commons Reconocimiento-No-ComercialSinObraDerivada 4.0 (CC BY-NC-ND 4.0) 
the third one, in the governance of cities and towns. Their participation in these three aspects was essential for the objectives of the monarchy, the high nobility and their own.

KEYWORDS: Castile; Juan II; Fernando de Antequera; military campaigns; military orders; sides; trades; $15^{\text {th }}$ century.

\section{INTRODUCCIÓN}

Como otras categorías conceptuales nobleza vieja o nobleza nueva, las que diferencian entre alta, media o baja nobleza nos sirven para entender mejor la composición, estructura, formas de organización y evolución de este importante grupo social ${ }^{2}$. Los conceptos de nobleza media y baja abarcan a una extraordinaria variedad de integrantes, podríamos decir que a la práctica totalidad de los que carecían de algún título, entre los que se incluía un número importante de los señores de vasallos y la aristocracia urbana. Desde un punto de vista social su procedencia era muy variada, desde caballeros villanos hidalgos enriquecidos, miembros de las órdenes militares a caballeros a sueldo del monarca y regidores ${ }^{3}$.

Como en el caso de la alta nobleza el prestigio, el poder y la riqueza se encargarán de establecer las diferencias entre ellos. Su servicio a la monarquía o a los grandes del reino se convirtió en fundamental a la hora de acometer empresas como las campañas militares, por ejemplo. Importantes parcelas de poder, aunque delegado, estaban en sus manos, baste citar las tenencias de fortalezas o numerosas encomiendas de las órdenes militares, así como el control de los gobiernos municipales. Además, en algunas regiones, como ocurrió en el reino de Córdoba, la importancia de la nobleza media fue muy destacable, mayor que en otras partes de Castilla ${ }^{4}$.

En el estudio de estos grupos durante los años de la minoría de Juan II de Castilla se han tenido en cuenta dos cuestiones. La primera ha sido no atribuir a este importante sector de la nobleza elementos - como el apellido- que son característicos de la alta nobleza o incluso de una parte determinada de la alta nobleza. La segunda es la menor exhaustividad con que se han estudiado ambos grupos de la nobleza, entre otras razones, por las dimensiones del área geográfica tratada, por el elevado número de sus integrantes o, simplemente, por el menor número de las fuentes conservadas que tratan sobre ellos.

2. Una síntesis general, pero interesante, sobre la nobleza es la que hace Mitre Fernández 1995, pp. 121-130.

3. Esta relación procede de Gerbet 1989a, p. 382.

4. Para esto último véase Quintanilla Raso 1982, p. 334. 


\section{LAS ACTIVIDADES MILITARES}

Desde un punto de vista cuantitativo es relativamente poco lo que sabemos acerca de las actividades militares de este grupo de la nobleza, sobre todo si se pone en relación con lo que se conoce de los representantes de los altos linajes. Para ello, basta con ojear cualquier crónica del reinado de Juan II y tomar como referencias las campañas militares del infante don Fernando contra los granadinos o la participación nobiliaria en los bandos que afectaron a algunas ciudades y regiones de Castilla. Excepción hecha de los testimonios documentales que dan cuenta de su ayuda al rey don Fernando de Aragón durante el interregno y en la campaña contra el conde de Urgel.

En relación con las cuestiones planteadas no creemos conveniente exponer aquí, a modo de inventario, todas aquellas ocasiones en que aparecen citados miembros de la nobleza media y baja. Sin embargo, nos parece más interesante poner de relieve el papel que jugaron en esas circunstancias, destacando a alguno de ellos.

Durante la campaña militar de 1407 en un elevado número de ocasiones en que miembros de la nobleza media y baja aparecen citados lo hacen en un papel subordinado. Así aparecen en relación con el almirante Alfonso Enríquez los patrones de las galeras que combatieron con las musulmanas en el Estrecho de Gibraltar ${ }^{5}$ o los integrantes de la casa del infante don Fernando encargados del transporte de los pertrechos de guerra desde Zahara a Setenil ${ }^{6}$. El papel de mayor responsabilidad que se les encomienda es el de alcaides de los castillos fronteros conquistados a los musulmanes durante esa campaña, casos de Zahara ${ }^{7}$, Torre Alháquime ${ }^{8}$, Priego, Las Cuevas y Cañete ${ }^{9}$. En el periodo entre campañas tienen protagonismo al lado de algunos grandes que habían quedado en la frontera, como ocurrió en tierras de Jaén en $1408^{10}$. Sin embargo, la práctica inexistencia de personajes de la alta nobleza que fueran fronteros -salvo casos como el de don Fadrique de Trastamara o el de García Fernández Manrique- y las especiales condiciones de vida de ese ámbito, con incursiones en el reino contrario y la vulneración de las treguas, proporcionaron protagonismo en acciones de ese tipo a miembros de la nobleza media y baja, ejemplos de lo cual fueron aquellas que los alcaides de Zahara y de Cañete dirigieron en $1408^{11}$.

En 1410 y con ocasión de la campaña militar contra los granadinos se mantiene alguna constante, como el encargo, en este caso a un miembro de la nobleza media, de que trasladase las bastidas, escalas y demás máquinas de guerra desde

5. Pérez de Guzmán 1953, p. 289.

6. Ibídem, pp. 292-293.

7. Ibídem, p. 292.

8. Ibídem, p. 299.

9. Ibídem, p. 300.

10. Ibídem, pp. 305-306.

11. Ibídem, pp. 307 y 307-308. Entre la historia y la leyenda parafraseando el título de Abellán Pérez 2016, pp. 69-80, estaría el enfrentamiento de cuatro caballeros hidalgos de Jerez de la Frontera con tropas nazaríes, seguramente en 1409. Veánse también Román de Cuenca 2012; Pangusión Cigales 2015. 
Sevilla hasta Antequera ${ }^{12}$. No dejan de ser excepcionales las alusiones al valor demostrado $^{13} \mathrm{o}$ a la muerte ${ }^{14}$ de alguno de estos nobles en combate. Muerte que en algunos casos suele ir ligada a la irresponsabilidad y a la juventud, como en las de varios caballeros fronteros en Jaén y en la del hijo del alcaide de Cañete ${ }^{15}$.

Como norma prácticamente general, en las relaciones de acompañantes del infante durante este periodo no se señalan los nombres de esos miembros de la nobleza media del reino, sino que se engloban bajo un genérico “... e otros muchos Caballeros" $" 16$.

Desde un punto de vista militar la conquista del trono de Aragón revistió distintas fases, en la primera de ellas, que tuvo lugar durante el interregno, varios miembros de la denominada nobleza "de servicio", que aquí podríamos encuadrar en la nobleza media, fueron muy importantes para lograr ese objetivo, entre otros se pueden citar a Álvaro de Ávila, a Pedro Gómez Barroso, a Diego González del Águila o a Lope de Rojas ${ }^{17}$. En los comienzos del reinado de Fernando I de Aragón, cuando su autoridad era contestada por el conde de Urgel, se destacaron personajes como Martín de Pomar o Suero de Nava ${ }^{18}$. No obstante, fue sobre todo en las operaciones militares y en el propio asedio a Balaguer en 1413 cuando miembros de la media y baja nobleza castellana tuvieron un papel relevante. En esas operaciones militares se destacaron Juan Delgadillo y Juan Carrillo que realizaron una correría sobre la población de Castellón de Farfaña ${ }^{19}$ o en la incursión que alguno de ellos protagonizó junto a Ruy Díaz de Quadros, Juan Carrillo de Ormaza, Sancho de Leyva, Tel González de Aguilar, Aznar de San Felices y otros ${ }^{20}$. Ya durante el cerco a Balaguer algunos integrantes de la nobleza media castellana como Pero Alfonso de Escalante, Álvaro Ruiz de Escobar y Gonzalo Rodríguez de Ledesma estuvieron entre los consejeros castellanos del monarca ${ }^{21}$, lo que puede dar idea de la consideración que le merecían. Además, durante el asedio Álvaro de Garavito se destacó por su valor ${ }^{22}$ y dio su vida Sancho de Leyva, caballero del adelantado Diego Gómez de Sandoval, que murió de un tiro de lombarda ${ }^{23}$. Incluso las tropas castellanas que llegaban para ayudar a tomar Balaguer, al poco de

12. Pérez de Guzmán 1953, p. 318. Fernán Rodríguez de Monroy.

13. Ibídem, p. 318. “... en la qual escaramuza se mostraron mucho Rui Díaz de Mendoza, hijo del Comendador de Estepa, e Juan Carrillo de Ormaza, a Anton García Gallego”.

14. Ibídem, p. 322. "Y en este día fue muerto de un pasador con yerba Martín Ruiz de Avendaño, un buen caballero Vizcaíno".

15. Ibídem, pp. 321 y 323.

16. Ibídem, pp. 288 y 301 , con ligeras variantes.

17. Ibídem, p. 338; García de Santa María 1972, p. 91; Zurita 1980², p. 115; García de Santa María 1982, p. 423.

18. Zurita $1980^{2}$, p. 323 .

19. Era propiedad de don Jaime de Urgel. Monfar y Sors Tomo X, 1853, p. 490.

20. Zurita $1980^{2}$, p. 344 .

21. Ibídem, p. 361. Este Gonzalo Rodríguez de Ledesma fue montero mayor del rey de Aragón, como consta en AHDZa., L.T, fols. 389v-390r, publicado por Lera Maillo, López Vallina, Lorenzo Pinar, Moreta Velayos y García Diego 1998, n. ${ }^{\circ}$ 156, pp. 145-146. El origen salmantino de este personaje lo destaca Villar y Macías vol. II, 1887, p. 8.

22. Zurita $1980^{2}$, p. 365.

23. Ibídem, p. 367. 
haberse conquistado, estaban al mando de hombres de linajes de la nobleza media. Alfonso Álvarez comendador mayor de León, Lope Álvarez su hermano y comendador de Ricote o Gonzalo Mexía comendador de Segura ${ }^{24}$. A diferencia de lo que habría ocurrido en las campañas granadinas la mayor relevancia que parece tener este sector de la nobleza se debió, sin duda, a la escasa presencia de miembros de la alta nobleza castellana, y quizá también a la narración que Zurita y García de Santa María hacen de los hechos ${ }^{25}$, además de a los testimonios documentales ${ }^{26}$.

Respecto a la participación de la media y baja nobleza en los bandos ciudadanos conocemos la implicación que tuvieron en ellos los regidores sevillanos, divididos entre partidarios de uno y otro de los grandes nobles que encabezaban las distintas facciones ${ }^{27}$. El relato de García de Santa María, que es a quien seguimos en este caso, y salvo en esa ocasión cita muy pocas veces los nombres de participantes en los bandos que no sean los cabecillas u otros altos nobles que les seguían. Llama la atención también que cuando se producen disputas entre caballeros del grupo que estudiamos aquí, porque pertenecieran a los bandos enfrentados, porque se utilizasen con fines como hacer daño al adversario, por poner a prueba las propias fuerzas, por incapacidad de controlar el impulso de recurrir a la violencia o, simplemente, para utilizarlos en beneficio propio, también aparezcan los nombres de los altos nobles. Esa última es, en efecto, la impresión que se saca de alguno de estos $\operatorname{casos}^{28}$. Se podría seguir con varios ejemplos más pero no harían más que abundar en lo ya expresado.

A pesar de ciertas similitudes en los bandos nobiliarios de Sevilla y de Murcia y de que en los de esta última ciudad los personajes implicados fueran de una menor relevancia social, la media y baja nobleza será un elemento fundamental en ellos, por ejemplo en los enfrentamientos entre Fajardo y Calvillo o en la resistencia al poder real encarnado en el condestable Dávalos. En Murcia el número de hidalgos fue cuantitativamente importante, del orden del veinticinco por ciento de la población, según el registro que los contabiliza en $1418^{29}$.

En el ámbito vasco, quizá más que en cualquiera de los ejemplos expuestos, es donde se manifiesta la gran importancia de todos estos linajes de la media y baja nobleza, sobre todo en relación con los bandos que se formaron entre ellos y que asolaron la tierra. En efecto, apellidos como Avendaño, Arteaga, Adán de Yarza, Aguirre, Aguirre de Zugasti, Arandia, Arancibia, Aranguren, Arbolancha, Arce, Artazubiaga, Ayala de Arandia, Basazabal, Baxaras, Butrón, Chabarria, Dehesa,

24. Ibídem, p. 374

25. Respecto al último cronista citado véase González Sánchez 2017, pp. 213-278.

26. Así lo pongo de manifiesto en mi trabajo "La presencia de hombres de armas castellanos en el cerco a Balaguer, 1413" (en prensa).

27. García de Santa María 1972, pp. 189-190. Entre los seguidores de Pedro de Stúñiga había más personas vinculadas al regimiento de la ciudad.

28. Como pudo ser aquel incidente en el que se vieron implicados hombres de doña Elvira de Ayala y hombres del tesorero de la Iglesia de Sevilla, en esa ciudad en 1417. García de Santa María 1972, pp. 198-199.

29. Lo ha publicado Torres Fontes 1963-1964, pp. 17-22, donde incluidas algunas mujeres se recogen cuatrocientos cincuenta y seis. Véase también el artículo de Menjot 1991, pp. 219-227. 
Dondiz, Galdes, Gamboa, Guecho, Guyara, Ibarresusi, Isasi, Landa, Leguizamón, Lezama, Lobo, Lupardo, Lusa, Marquina, Martiarto, Maurica, Menchaca, Mendieta, Meñaca, Muxica, Olabarrieta, Oquela, Ospina de Mariaca, Palacio, Retuerto, Sagarminaga, Salcedo, San Pedro, Taramona, Uba, Ugarte, Uribe, Urrutia, Yarza, Yarzu de Salcedo, Zangroniz, Zárate, Zugasti y Zulmezu, son algunos de muchos que estuvieron implicados en esas revueltas ${ }^{30}$. Solo los Ayala y, en menor medida, los Velasco, entre los miembros de la alta nobleza del reino, tuvieron alguna participación y, por lo que parece, de forma esporádica.

Galicia también estuvo mediatizada en numerosos aspectos por la proliferación e importancia que tuvieron los linajes de la media y baja nobleza, por citar un solo caso en la Hermandad de Santiago de 1418. Andeiro, Andrade, Coiro, Mariño, Mesía, Moscoso, Lobeira, Ozores, Pallarés, Pardo, Rivadeneira y Seijas ${ }^{31}$ fueron linajes que lograron sobrevivir en una región tan señorializada, por lo general, a costa de su servicio a los grandes, de la extorsión a las propiedades de la Iglesia o de la que ejercían sobre sus vasallos.

Por lo general, los linajes de la media y baja nobleza necesitaron del auxilio de los grandes para su promoción y, lo que es más importante, para su supervivencia, de ahí que las relaciones feudovasalláticas se convirtieran como norma general en indispensables, quizá más en las regiones más alejadas de la frontera con el reino de Granada y fuertemente señorializadas. Tampoco debe olvidarse la necesidad que sienten los grandes de esa ayuda, sobre todo de tipo militar, para lograr los objetivos más diversos, pero que podemos concretar en ampliar su poder, prestigio e influencia. Sin duda, esto fue importante en un periodo en el que las campañas militares contra los granadinos serían un medio de ostentación del poder por parte de la alta nobleza.

\section{LA PRESENCIA NOBILIARIA EN LAS ÓRDENES MILITARES}

Durante la minoría de Juan II el control de las órdenes militares recayó en personas encumbradas en lo que hemos considerado la más alta nobleza del reino, aunque procedieran de la "nobleza de servicio". Así ocurrió con don Lorenzo Suárez de Figueroa maestre de Santiago, incluso hubo miembros de la propia familia real, como don Enrique de Villena, que fue maestre de Calatrava o los infantes Sancho y Enrique, que lo fueron de Alcántara y de Santiago, respectivamente, aunque quien realmente controlara esas órdenes fuera su padre, el infante don Fernando. Sin embargo, no es menos cierto que personajes de rango mucho menor fueron maestres de las órdenes militares, caso de Juan de Sotomayor, por poner solo un ejemplo. Esencialmente aquí no nos ocupamos de ellos, lo hacemos de cargos situados jerárquicamente por debajo en el organigrama de las órdenes,

30. El listado procede de Guerra 1930, pp. 8-199, que lo elabora de la información que proporciona García de Salazar vol. IV, 1967.

31. López Ferreiro vol. VII, 1983; Aponte 1986. 
aquellos ejercieron individuos de la nobleza media y baja. Algunos de estos nobles, segundones en algún caso ${ }^{32}$, encontraron en las órdenes militares un medio para retrasar su decadencia social, al menos en una generación ${ }^{33}$.

La Orden de Santiago durante el maestrazgo de Lorenzo Suárez de Figueroa ${ }^{34}$ tuvo como comendador mayor de la provincia de Castilla a García Fernández de Villagarcía, personaje que aspiró a sucederle al frente del maestrazgo ${ }^{35}$, lo que motivó su enfrentamiento con el infante don Fernando ${ }^{36}$. Sin embargo, por su renuncia obtuvo la concesión de una importante cantidad de dinero ${ }^{37}$, de ahí que poco después lo veamos interviniendo en la campaña de 1410, donde figura desde sus $\operatorname{comienzos}^{38}$, en la toma de la Sierra Rabita ${ }^{39}$, en la batalla de la Boca del Asno ${ }^{40}$, en el combate que se tenía que dar a Antequera el 27 de junio $^{41}$ y en el momento del ataque final ${ }^{42}$.

García Fernández de Villagarcía logró en 1408 la confirmación de todas las mercedes y privilegios que tenía de los monarcas anteriores ${ }^{43}$ y meses después, y de forma concreta, de veinte excusados del pago de monedas, dieciséis de los cuales tendría en La Pobla ${ }^{44}$ y cuatro en Bonaval, por los servicios prestados en la guerra en tiempos de Enrique III y en los actuales ${ }^{45}$. En 1411, sin duda por una razón similar, se le expidieron los traslados de dos concesiones. La primera era la de Villagarcía, que había sido de sus abuelos y que pertenecía a la Orden de Santiago que, en compensación, pasaría a percibir 10.000 maravedíes anuales en la cabeza de pecho de los judíos, en la tierra de dicha villa. Y la segunda concesión ratificaba la de Juan I para que pudiese edificar en Villagarcía una casa fuerte y hacerla alcázar, ponerle pretil, almenas, cava y barreras ${ }^{46}$.

32. Uno de ellos fue Luis Venegas, comendador de Cazalla, y hermano de Egas Venegas, señor de Luque. CVV., Extracto Archivo Casa Bailío, vol. 273, f. 180v, n. ${ }^{\circ}$ 7, f. 2.

33. Gerbet 1989b, p. 163. Es una traducción abreviada de su tesis citada páginas atrás.

34. Rodríguez Amaya 1950, pp. 241-302; Mazo Romero 1980, pp. 64-87, en especial.

35. Su padre, del mismo nombre, había precedido en el maestrazgo de la orden a don Lorenzo Suárez de Figueroa. Rades y Andrada 1980, f. 53v.

36. Pérez de Guzmán 1953, p. 315; Rades y Andrada 1980, f. 56r; García de Santa María 1982, p. 289. Basándose en las crónicas del reinado, aunque la edición sea anterior a las recogidas aquí para éstas, también puede verse en Caro de Torres 1629, f. 38v. Al haber sido Extremadura el escenario principal lo recoge del Pino García 1991, pp. 167-168.

37. Cifrada en quinientos mil maravedíes, como señalan Pérez de Guzmán 1953, p. 315, y Rades y Andrada 1980, f. 56r.

38. Pérez de Guzmán 1953, p. 317; García de Santa María 1982, p. 294.

39. García de Santa María 1982, p. 297.

40. Pérez de Guzmán 1953, p. 320; García de Santa María 1982, p. 307.

41. Pérez de Guzmán 1953, p. 322; García de Santa María 1982, p. 319.

42. García de Santa María 1982, p. 381.

43. AHN., Sección Nobleza. Osuna, carp. 35, n. ${ }^{\circ}$ 3; RAH., Col. Salazar y Castro, M-48, ff. 200v-201v.

44. Debe tratarse de la Puebla de Ferrant González, en el obispado de Badajoz, nombre con el que aparece en un documento de confirmación de 1414. AHN., Sección Nobleza. Osuna, carp. 37, n. ${ }^{\circ} 2$.

45. AHN., Sección Nobleza. Osuna, carp. 37, n. $^{\circ} 1$.

46. AHN., Sección Nobleza. Osuna, carp. 35, n. ${ }^{\circ} 22$. 
García Fernández de Villagarcía debió morir antes del 9 de junio de 1414, pues Juan II confirma a su hijo García, en esa fecha, la merced de los veinte excusados del pago de monedas que le había hecho a su padre ${ }^{47}$.

La encomienda mayor de la provincia de León ${ }^{48}$ recayó en un familiar del maestre y homónimo Lorenzo Suárez de Figueroa. De este personaje conocemos bastante bien las acciones de armas en que intervino durante los años 1407 y 1410 . En el primero de ellos, antes del inicio de la campaña militar, salió voluntario para abastecer Teba y corrió la comarca de Antequera ${ }^{49}$ y se le ordenó reparar y guardar Bedmar $^{50}$. En la campaña de 1410 iba en la primera batalla a la entrada del ejército castellano en tierras granadinas ${ }^{51}$, reconoció el real que los infantes nazaríes tenían cerca de Antequera $^{52}$, quedó encargado del que estableció el infante cuando éste marchó a la Boca del Asno ${ }^{53}$, así como de una manta que los moros quemaron en una de sus salidas ${ }^{54}$. También se le cita en el combate que se tenía que dar a Antequera el 27 de junio ${ }^{55}$, en una correría sobre Málaga ${ }^{56}$, en el momento del asalto final a Antequera ${ }^{57}$ y tras su conquista en la toma de varios castillos que la protegían $^{58}$. En 1412 es uno de los caballeros castellanos que salieron con el rey de Aragón de Zaragoza para combatir al conde de Urgel $^{59}$.

Su cargo e influencia en la orden fueron algunas de las razones que movieron al infante don Fernando a dirigirse a él, tras la muerte de don Lorenzo Suárez de Figueroa, para que junto con los comendadores de la provincia de León, dieran las voces a su hijo, el infante Enrique como maestre ${ }^{60}$. De la cercanía y confianza de su pariente, el maestre fallecido, dan cuenta que le dejara entre sus albaceas testamentarios, con la misión de cumplir las mandas que hace en Tierra de León ${ }^{61}$

47. AHN., Sección Nobleza. Osuna, carp. 37, n. ${ }^{\circ}$ 2. La sucinta biografía de García Fernández de Villagarcía en González Sánchez 2013, pp. 60-61.

48. La extensión de la provincia de León de la Orden de Santiago, que en lo eclesiástico formaba el obispado-priorato de San Marcos de León, comprendía en Extremadura los provisioratos de Llerena y de Mérida y fuera de Extremadura: Barruecopardo (Salamanca), Villanueva del Ariscal (Sevilla), Villalba de la Lampreana (Zamora), Destriana (León), Benamejí (Córdoba), Quintela (Orense), Porto (Zamora) y Villar de Santos (Orense). Mota Arévalo 1969, pp. 429-430.

49. García de Santa María 1982, p. 124.

50. Ibídem, pp. 128-129.

51. Pérez de Guzmán 1953, p. 317; García de Santa María 1982, p. 294.

52. Pérez de Guzmán 1953, p. 319; García de Santa María 1982, p. 302.

53. Pérez de Guzmán 1953, p. 320.

54. Ibídem, p. 322.

55. Pérez de Guzmán 1953, p. 322; García de Santa María 1982, p. 319.

56. Pérez de Guzmán 1953, p. 324; García de Santa María 1982, p. 326.

57. García de Santa María 1982, p. 381.

58. Pérez de Guzmán 1953, p. 331; García de Santa María 1982, pp. 392-393.

59. Pérez de Guzmán 1953, p. 347.

60. García de Santa María 1982, p. 289. Esa carta a la que se refiere García de Santa María no nos ha llegado, por el contrario sí que contamos con el documento en el que el infante se dirige a Gome Suárez de Figueroa y le pide que “... fabledes con el comendador mayor de la tierra de Leon e con todos esos otros cavalleros comendadores criados del maestre e parientes e amigos vuestros commo luego en punto se ayunten e fagan su esleçión e den sus vozes al dicho don Enrique, mi fijo, para que sea maestre". ADM., Archivo Histórico, leg. 341, n. ${ }^{\circ}$ 11, publicado por Mazo Romero 1980, n. ${ }^{\circ}$ 5, p. 563.

61. RAH., Col. Salazar y Castro, D-10, s/f. y M-5, ff. 76r-77v. 
y de que le haga tutor de uno de sus hijos, por lo que manda que se le entreguen 70.000 maravedíes $^{62}$.

La última noticia que tenemos de él es de 31 de mayo de 1419, por la que sabemos que tenía un pleito con los vecinos del concejo de El Bodonal a los que impedía la entrada en las tierras y dehesas comarcales ${ }^{63}$.

En un nivel inferior al considerado se encontraban los comendadores que tenían a su cargo las distintas encomiendas de la orden ${ }^{64}$. En el caso de la Orden de Santiago hubo hasta noventa y $\operatorname{dos}^{65}$-aunque Rades contabiliza treinta y nueve encomiendas ${ }^{66}$ - algunos de cuyos tenentes tenían también la condición de "treze". Entre esos treinta y nueve comendadores solo encontramos a cuatro que se puedan considerar de la alta nobleza, aunque en algún caso fueran de ramas segundonas del linaje principal. En esas circunstancias estuvieron Pedro López Fajardo, Diego Hurtado de Mendoza, Gómez de Sotomayor, Juan de Mendoza y Pedro Vélaz de Guevara ${ }^{67}$. El resto integrarían lo que hemos denominado nobleza media.

De algunos comendadores de la Orden de Santiago durante los años de nuestro estudio podemos proporcionar unos breves rasgos biográficos. Por ejemplo, de García González de Céspedes que entró en la orden en 1416 y que siguió siempre el partido del infante don Enrique, su maestre, que le dio la encomienda de Mérida y los bastimentos de Tierra de León ${ }^{68}$. Al frente de la encomienda de Mérida se debía encontrar a fecha 9 de mayo de 1416, momento en que el maestre le manda no entrometerse en las cosas del concejo y guardarle sus privilegios, usos y costumbres y todavía en 1420, en que se le ordena dejar al concejo dar solares para casas y adheridos para molinos, como lo tenían por costumbre, no entrometerse ni hallarse en las elecciones de oficios que hiciese el concejo, ni hacer bandos ni parcialidades contra ello ${ }^{69}$. Lope Íñiguez de Orozco, pariente del obispo de Orense

62. RAH., Col. Salazar y Castro, M-5, ff. 77v-79v.

63. Collantes de Terán Delorme 1980, n. ${ }^{\circ}$ 68, p. 42. Los datos de esta biografía en González Sánchez 2013, pp. 61-62.

64. El organigrama con la disposición jerárquica de los cargos y oficios en la orden la desarrolla Rodríguez Blanco 1985b, pp. 176-192, especialmente.

65. Porras Arboledas 1981, 2 vols. Una relación de las encomiendas de las dos provincias puede verse en Salazar y Castro 1949. En la Provincia de León y en la actual Extremadura a finales de la Edad Media los dominios de la Orden de Santiago abarcaban una superficie de unos 10.000 km², según Cabrera Muñoz 1987, p. 135.

66. Sin embargo, no cuenta entre ellas a la de Estepa que, en los años que estudiamos, tuvo a su frente a Pedro Fernández de Valenzuela (en torno a 1406) y a Lope Álvarez de Hinestrosa (por el año 1410). Sobre estos personajes trata Lasarte Cordero 1956, pp. 104-105, y de forma específica 107 y 110.

67. Rades y Andrada 1980, f. 55r-v. Sobre Juan de Mendoza son interesantes los rasgos biográficos que porporciona sobre él Sánchez Saus 1991, p. 192, del que señala que fue comendador de Orcajo, investido caballero por mano del infante don Fernando, alcaide del castillo de El Bollo, e investido pertiguero mayor de tierra de Santiago por su tío el arzobispo de Santiago don Lope de Mendoza. Respecto a Pedro Vélaz de Guevara, comendador de Oreja y su condición de ricohombre de Castilla en el reinado de Juan II véanse Zumalde 1957, pp. 49-50, y Ayerbe Iríbar 1985b, nota 2, p. 170. Sobre el linaje Guevara consúltese el artículo de García Fernández vol. I, 2009, pp. 387-405.

68. Díaz Ballesteros vol. II, 1873, p. 209.

69. RAH., 9/5574, f. 247r-v. 
don Pedro Díaz de Orozco, que alcanzó el cargo de comendador de Biedma y de Villanueva y que en 1408 fue testigo de la carta de arras que Gome Suárez de Figueroa otorgó a doña Elvira Laso de Mendoza ${ }^{70}$. El doctor Fernando González de Ávila que fue uno de los comendadores ilustres de la encomienda de Beas de Segura era oidor de la Audiencia del rey, así como canciller mayor y juez mayor de la casa del maestre de Santiago el infante don Enrique ${ }^{71}$. Gutierre de Torres, maestresala del monarca y al que le concede el alguacilazgo mayor de Arévalo de por vida, también tenía una encomienda de Santiago en $1419^{72}$. O Vidal de Soto comendador de Caravaca entre 1413 y $1426^{73}$, que fue uno de los embajadores de la Orden de Santiago en el concilio de Constanza ${ }^{74}$. Por citar algunos ejemplos.

La organización que seguían las órdenes de Alcántara y de Calatrava en este caso era esencialmente la misma que la señalada para la de Santiago, si bien en éstas, en la documentación y en las obras manejadas, aparece entre los cargos más elevados el de clavero ${ }^{75}$.

En el caso de la Orden de Alcántara conocemos los nombres del comendador mayor y el del clavero de la orden a la muerte del maestre Fernán Rodríguez de Villalobos en $1408^{76}$. El primer cargo lo tenía Francisco Ruiz García y el segundo Juan Martínez Simón ${ }^{77}$. Sin embargo, difieren las distintas fuentes a la hora de proporcionar el número de encomiendas y, por lo tanto, el de comendadores que tenía esta orden. Según la relación que se contiene en las Definiciones y constituciones hechas en el capítulo general celebrado en Ayllón el 25 de agosto de 1411 había un comendador mayor, un clavero y veintitrés comendadores, excluyendo el que se ocupaba de los diezmos ${ }^{78}$. Esto concuerda con lo que expone Rades para quien habría un comendador mayor, un clavero y veintitrés comendadores ${ }^{79}$. Por lo que de seguir estas dos fuentes entre ellos solo encontramos a uno de un linaje más relevante, el comendador mayor de apellido Sotomayor. Sin embargo, si tomamos como referencia a Torres y Tapia, que rectifica en muchos casos lo que Rades afirma, no habría en los momentos de nuestro estudio más que doce encomiendas

70. Salazar y Castro 1959, pp. 93-94.

71. Porras Arboledas vol. I, 1981, p. 321. Según consta en la obra de Carramolino Martín vol. II, 1872, p. 419, su nombre era Fernán González de Valderrábanos y fue uno de los dos procuradores que tuvo la ciudad de Ávila en las Cortes que el infante don Enrique mandó hacer en ella en 1420. Las referencias documentales sobre este personaje son bastante numerosas.

72. Martel 1967, pp. 98-99.

73. Rodríguez Llopis 1986, p. 122.

74. Es uno de los que consta como embajador de la orden en la sesión XXXV del Concilio. Aguado de Córdova, Alemán y Rosales y López Urguleta 1719, p. 374. Goñi Gaztambide 1965, pp. 199-203.

75. En cualquiera de ellas la jerarquía iba en orden descendente del maestre al comendador mayor para acabar en los comendadores. García Vera y Castrillo Llamas 1993, pp. 31-33.

76. Fue elegido cuando desempeñaba el cargo de clavero de la orden, como señala Rades y Andrada 1980, f. 34r-v.

77. Torres y Tapia 1999, p. 205, de quien lo debe tomar del Pino García 1991, p. 163.

78. Lomax 1981, p. 764, especialmente. La procedencia del documento y las páginas que ocupa, $763-773$.

79. Rades y Andrada 1980, ff. 34v-35r. 
y ningún comendador perteneciente a la alta nobleza ${ }^{80}$, de la que excluimos a un hijo natural de Pero Niño, futuro conde de Buelna.

Entre los comendadores de esta orden destacamos a Gonzalo Álvarez de Villasayas, comendador de Santibáñez que fue uno de los dos embajadores que su orden envío al concilio de Constanza, aunque tuvo que regresar a España por enfermedad ${ }^{81}$.

Siguiendo a Rades, la Orden de Calatrava contaba, por debajo del maestre con un clavero, un subclavero y once comendadores ${ }^{82}$. En esta orden la proporción de comendadores pertenecientes a linajes de la más alta nobleza del reino es escasa, solo si se considera entre ellos al maestre -durante el gobierno de don Luis de Guzmán-y al clavero se pueden señalar dos miembros del linaje Guzmán.

Precisamente el clavero era Ramiro Núñez de Guzmán señor de Toral, que figura entre los miembros del ejército castellano a comienzos de la campaña del cerco a Antequera ${ }^{83}$. De él sabemos también que en 1417 se encontraba en Sevilla, por mandato del maestre de la orden, “... con cierta gente de armas para ayuda de la justicia y para hacer lo que cumpliese al servicio del rey", sin duda con motivo de los bandos nobiliarios, por lo que el concejo de esta ciudad ordena al mayordomo que le prestase 5.000 maravedíes para su mantenimiento, mientras le llegaba su libramiento y el sueldo de la gente de armas que tenía ${ }^{84}$. A mediados de 1418 el rey expedía una carta de seguro a favor de la Hermandad de Villa Real, frente al maestre y al clavero de la Orden de Calatrava, pues los hermanos se quejaban de recibir daños al ir a cobrar la asadura a tierra de la orden ${ }^{85}$. Y el 8 de agosto del mismo 1418 Juan IV de Morimond dispensa a nuestro personaje, junto con el maestre y con el comendador de Zorita, que pueda disponer de sus bienes muebles ${ }^{86}$.

Como ocurre a otro nivel con la corona y la alta nobleza, el sistema de encomiendas era una forma más de transferir parte de la renta generada a los estamentos más bajos de la nobleza que, además, de esa manera, se veían involucrados en el gobierno de una parte del territorio y podían encontrar una vía de promoción. Además, les pudieron servir para consolidarse en ámbitos locales y regionales

80. Torres y Tapia 1999, pp. 201-202.

81. AV., Reg. Supll, vol. 106, ff. 294v-295v, publicado por Goñi Gaztambide 1965, n. ${ }^{\text {o }}$ 9, pp. 303-305, y en Colección diplomática 2000, n. ${ }^{\circ} 806$, pp. 556-559. Un regesto del mismo en Corral Val 1999 , n. ${ }^{\circ} 205$, pp. 372-373.

82. Rades y Andrada 1980, ff. 67v-68r.

83. Pérez de Guzmán 1953, p. 317; García de Santa María 1982, p. 295. En la primera de las crónicas aparece como señor de Toral y en la segunda como merino de las Behetrías.

84. Collantes de Terán Delorme 1980, n. ${ }^{\circ} 27$, p. 13.

85. AHN., Diversos, leg. 1, n. ${ }^{\circ}$ 14, regesto en Sánchez Benito 1990, n. ${ }^{\circ}$ 49, p. 33. La renta de la asadura fue junto al patrimonio inmobiliario que reunió lo que la permitió sobrevivir a lo largo del siglo XV, como señala Álvarez de Morales 1985, p. 97. Sobre esta misma cuestión véase de Urosa Sánchez 1998, el cap. VIII Los recursos económicos de la Hermandad', pp. 119-142, donde hace un exahustivo estudio de la renta de la asadura.

86. O'Callaghan 1996, n. ${ }^{\circ}$ 9, p. 124. Sobre Zorita trata el artículo de Fernández Izquierdo 1986 , pp. 391-420, donde, entre otras cuestiones, se tratan los orígenes del dominio de la Orden de Calatrava y, lo que es más interesante para nosotros, los contenciosos y problemas del concejo durante la minoría de Juan II, con un breve regesto documental en la parte final. 
donde ya tenían fijados sus intereses ${ }^{87}$. Sin embargo, no hemos podido documentar ningún caso de comendadores que tuviesen un señorío propio y la encomienda de una orden militar en los años estudiados.

Por otra parte, aunque en las diferentes órdenes militares existieron encomiendas alejadas de las fronteras, es necesario destacar aquí aquellas otras cercanas a los ámbitos portugués y granadino. En la primera de esas zonas la Orden de Santiago contaba con ochenta y dos poblaciones, integradas en la provincia de León y se extendía de Norte a Sur -desde Torremocha hasta Monesterio y Guadalcanal- por la parte occidental de las actuales provincias de Cáceres y Badajoz ${ }^{88}$. En la actual provincia de Badajoz una de las principales encomiendas de la Orden de Santiago fue la de Mérida ${ }^{89}$. Mérida, Alange y Montánchez eran algunas de las importantes fortalezas que la Orden de Santiago tenía en esta zona, pues contaba con varias más a lo largo de la frontera con Portugal. La importancia estratégica de éstas la señala el infante don Fernando, tras la muerte del maestre de Santiago don Lorenzo Suárez de Figueroa, cuando intentaba conseguir el maestrazgo para su hijo Enrique, en una carta que dirige a Benedicto XIII para que aprobara sus aspiraciones ${ }^{90}$. En este sentido es importante indicar que el maestre de Santiago don Enrique de Aragón, fruto de la herencia recibida pasó a controlar las fortalezas de Alburquerque, Ledesma, Miranda, Montemayor, Granada, Galisteo, Las Garrovillas, Medellín, La Codosera, Alconchel y Alconetar o Azagala.

La Orden de Alcántara tenía sus encomiendas en Extremadura agrupadas en dos partidos, que eran Alcántara y La Serena ${ }^{91}$. Las encomiendas que esta orden tenía eran Zalamea ${ }^{92}$, Valverde ${ }^{93}$, Alcántara, Valencia de Alcántara ${ }^{94}$, Magacela, Villanueva de la Serena y Cabeza de Buey ${ }^{95}$, Torre de San Miguel ${ }^{96}$ y Santibáñez ${ }^{97}$.

En el sector granadino occidental encontramos las encomiendas de Morón, que pertenecía a la Orden de Alcántara $^{98}$, Osuna a la de Calatrava ${ }^{99}$ y Estepa a la

87. Peinado Santaella 1991, p. 418.

88. Mapa de la Provincia de León en 1500 publicado por Rodríguez Blanco 1985a, s/p.

89. RAH., 9/5574, f. 247r-v.

90. AV., Instrumenta Miscellanea, vol. 4607, ff. 1r y 3r, publicado por Suárez Fernández 1960, n. ${ }^{\circ}$ 84, pp. 286-287; regesto en Milian Boix 1969, n. ${ }^{\circ}$ 653, p. 294; y regesto en Colección diplomática 2000 , n. ${ }^{\circ} 763$, p. 527.

91. Ladero Quesada 1982, p. 510.

92. ADM., Archivo Histórico, leg. 243, n. ${ }^{\circ} 51$ bis; RAH., Col. Salazar y Castro, M-5, f. 199r, publicado en Colección diplomática 2000, n. ${ }^{\circ}$ 800, pp. 552-553. También en Torres y Tapia 1999, p. 209.

93. AN/TT. Gavetas, n. ${ }^{\circ}$ XVIII, maço 6, n. ${ }^{\circ}$ 13, en As Gavetas 1970, n. ${ }^{\circ}$ 4469, pp. 666-671, regesto en Colección diplomática 2000, n. $^{\circ} 773$, p. 534.

94. Alcántara y Valencia de Alcántara eran dos de las fortalezas más cercanas e importantes a la raya con Portugal como señala Castrillo Llamas vol. II, 1997, p. 535.

95. Estas cinco poblaciones las cita Torres y Tapia 1999, p. 209. Referencias también en Colección diplomática 2000, n. ${ }^{\circ} 762,764,765,767$, pp. 527 y 528.

96. El documento está publicado por Torres González 1988, pp. 308-309, y cuenta con un breve regesto en Colección diplomática 2000, n. ${ }^{\circ} 768$, p. 528.

97. AV., Reg. Avin, vol. 328, ff. 207-208, publicado en Colección diplomática 2000, n. ${ }^{\circ}$ 801, pp. 553-555.

98. Sobre esta población véanse las obras de González Jiménez 1987, pp. 401-422; 1988 y 1992.

99. Viña Brito 1991. 
de Santiago ${ }^{100}$. Esta última orden tenía bajo su dominio importantes posesiones en la zona oriental, baste recordar las encomiendas de Segura de la Sierra -centro de la encomienda mayor de Castilla-, Beas de Segura, Yeste ${ }^{101}$, Sócovos, Ferez ${ }^{102}$, Moratalla $^{103}$, Caravaca, Aledo ${ }^{104}$, Lorquí, Murcia ${ }^{105}$, Ricote ${ }^{106}$ y Cieza ${ }^{107}$. Desde un punto de vista cuantitativo se ha estimado que la Orden de Santiago, desde Segura a La Sagra contaba con unos $1.000 \mathrm{~km}^{2}$, los mismos que la Orden de Calatrava en el sector jiennense con la encomienda de la Peña de Martos ${ }^{108}$, de la que dependían Martos, Torredonjimeno, Lopera, Porcuna y otras aldeas y las de Torres, Canena, Jimena, Recena ${ }^{109}$ y Vívoras ${ }^{110}$. Además, eran posesiones de la Orden de Calatrava en el ámbito fronterizo granadino Alcaudete, Locubín, Priego, Zambra, Carga, Algar, Carcabuey y Albendín ${ }^{11}$.

Así pues, estas encomiendas fronterizas se insertaban en el sistema defensivo castellano, por lo que eran normales la vigilancia ${ }^{112}$, para prevenir cualquier incursión granadina, por ejemplo una procedente de Guadix y Baza en el campo de Caravaca, de la que informaron los comendadores de esa población y de Archena a Lorca y a Murcia, respectivamente, en octubre de $1420^{113}$, y las comunicaciones, dando aviso de los movimientos de tropas del otro reino en el área fronteriza, como tenemos noticia de que ocurrió entre el alcaide de Alcalá la Real y el comendador mayor de Calatrava ${ }^{114}$. También los comendadores de algunas de esas

100. Lasarte Cordero 1956, pp. 101-122. La pertenencia de la encomienda de Estepa a la Orden de Santiago y su emplazamiento estratégico cercano a la frontera con el reino de Granada la señala Garza Cortés 1996.

101. Sobre esta encomienda Rodríguez Llopis 1982.

102. Sobre su cercanía a la frontera granadina, y su población mudéjar que habría ayudado a almogávares musulmanes en 1420, da cuenta Torres Fontes 1961, p. 95.

103. Véase, por ejemplo, AMM., Cartulario Real 1411-1429, f. 5, publicado por Rodríguez Llopis 1988, n. $^{\circ} 8$, pp. $76-77$.

104. Munuera y Abadía 2000, p. 117.

105. Los palacios que la orden tenía en la ciudad, en la colación de San Nicolás, se los entregó el infante don Fernando al doctor Alfonso Fernández de Cascales. La confirmación del infante don Enrique de Aragón está fechada en Segovia el 24 de diciembre de 1427. AMM., Cartulario Real 15351554, ff. 5v-16r.

106. Su comendador cobraba el portazgo a los que pasaban por el puerto de La Losilla. Torres Fontes 1982b, 66-69, especialmente.

107. La relación de estas encomiendas procede de Torres Fontes 1965-1966, pp. 325-348, y está fechada en 1468.

108. Tapia Garrido vol. IV, 1991, pp. 71-73.

109. Rodríguez Molina 1974-1975, pp. 74-81. Jimena y Recena se incorporaron al señorío de la orden en 1434, como señala Solano Ruiz 1978, p. 62. La relación en Arquellada 1996, pp. X-XI.

110. Argente del Castillo Ocaña vol. I, 1991, p. 302.

111. Menache 1986, p. 641.

112. El maestre don Lorenzo Suárez de Figueroa se dirige al comendador de Aledo, el 17 de agosto de 1407, y entre otras cosas le ordena “... que tuviera siempre en la Casa pública y en la población centinela y ronda para prevenir cualquier atentado de los moros fronterizos, con quienes se hallaba en guerra”. Munuera y Abadía 2000, p. 117. En Morón se cogieron dos pechos en 1411 que sirvieron en parte para pagar ciertos servicios de vigilancia y atalaya, como recoge González Jiménez 1987, p. 409.

113. Canovas Cobeño 1980, p. 285.

114. Regesto en Juan Lovera 1977, n. ${ }^{\circ} 55$, pp. 41, y publicada por la misma en 1988, n. $^{\circ} 59$, p. 88 . 
encomiendas desempeñaron un papel claramente ofensivo así consta, por ejemplo, en una de las expediciones de castigo a tierras granadinas organizada desde Murcia y previa a la campaña de 1407, cuando los comendadores de Aledo, Archena, Caravaca y Sócovos atacaron la comarca de Vera ${ }^{115}$. En ese mismo contexto se enmarca la conquista de Pruna donde se destacó García de Peñaranda, comendador de la Orden de Alcántara en Morón ${ }^{116}$. Y en 1410, y previa a la campaña militar, tuvo lugar la intervención de gente de esta encomienda, bajo la dirección de su comendador Álvaro de Chércoles ${ }^{117}$ en la reconquista de Zahara ${ }^{118}$.

Lo expresado antes puede dar idea del importante potencial militar tanto estático como dinámico de las órdenes. Sin embargo, ignoramos el número de lanzas que las órdenes militares eran capaces de movilizar, de ahí que tengamos que contentarnos con datos muy escasos. Uno importante es el que señala que a comienzos de junio de 1407 los maestres de Santiago y de Alcántara, que estaban en Écija para incorporarse al grueso del ejército castellano, enviaron doscientas lanzas con la recua que tenía que abastecer Pruna ${ }^{119}$. Al margen de ello, conocemos datos de momentos cercanos, pero posteriores a los años que estudiamos aquí y otros de carácter fragmentario. Así, según Torres Fontes, las encomiendas que la orden militar de Santiago tenía en el reino de Murcia servían con setenta y siete lanzas en $1468^{120}$. Además, contamos con noticias dispersas sobre caballeros de la orden, si bien en este caso su cuantía es tan reducida que no nos permite hacernos una idea aproximada de cómo sería en la realidad. Así ocurrió con Suer Vázquez de Moscoso, comendador de Santiago y veinticuatro de Sevilla, que recibió 7.300 maravedíes en los años 1408 y 1409 en concepto de tierra por cinco lanzas ${ }^{121}$; o con Diego García Pardo, comendador de Bedmar y con el comendador de Segura, que tenían un vasallo con una lanza y un vasallo con un caballo, respectivamente, en Baeza, según el padrón de $1407^{122}$.

En otro orden de cosas, otra parcela de poder dentro de los territorios de las órdenes militares, era la concejil. En este ámbito y no solo en su función rectora sino en la judicial encontraron su inserción de forma mayoritaria letrados que

115. Pérez de Guzmán 1953, p. 279. Sin mencionar la crónica de la que lo toma, pero expresando que es del reinado de Juan II, da cuenta de la intervención en esta expedición de García López de Cárdenas, comendador de Sócovos, Fuster Ruiz 1978, p. 235. Ya hemos señalado que la cuantificación de la gente que tomó parte en esta operación la hizo Arco y Molinero 1899, p. 166, de quien lo toma Tapia Garrido vol. IV, 1991, p. 273.

116. Collantes de Terán y Caamaño 1990, p. 81.

117. Ibídem, p. 92.

118. Pérez de Guzmán 1953, p. 316, que solo da cuenta de la intervención del "Governador de Alcántara".

119. Ibídem, p. 287.

120. Torres Fontes 1965-1966, pp. 325-348. Curiosamente, en un documento correspondiente a 1615 el número de lanzas de estas encomiendas difiere en su asignación, pero el cómputo final arroja la cifra de 78 lanzas, una más que en 1468. Montoya 1988, p. 535.

121. Vilaplana 1974, p. 441, de donde lo toma Sánchez Saus 1991, p. 208. 91-93.

122. AGS., Guerra Antigua, leg. 1313, ff. 1 y 2, publicado en Censo de población 1829, pp. 
serán los que se ocupen de ella ${ }^{123}$. En efecto, las formas de relación entre maestre y comendadores, por una parte, y concejos, por otra, se modificaron con la introducción de los alcaldes mayores, cuya función consistía en la resolución de los pleitos pendientes, que no podían solventar ni comendadores ni alcaldes ordinarios por falta de preparación. Sustituirán en parte a los comendadores en los juicios de apelación o segunda instancia, y aunque en principio solo desempeñaron esa función, en tiempos del maestrazgo de don Lorenzo Suárez de Figueroa se les permitió resolver los pleitos comunes, los de primera instancia, en los lugares por donde pasasen, donde además visitan la cárcel, otorgan ordenanzas, nombran los cargos concejiles en caso de desacuerdo o los sustituyen en caso de negligencia ${ }^{124}$.

En la época en que centramos nuestro estudio encontramos referencias a los alcaldes mayores entre los testigos del testamento de don Lorenzo Suárez de Figueroa, cuando se nombra como tales a Mateo Sánchez, bachiller en Leyes y a Gonzalo Alfón Román ${ }^{125}$. Desempeñando funciones judiciales contamos con los casos de Juan Fernández de Trujillo, alcalde mayor de Juan de Sotomayor, gobernador de la Orden de Alcántara, a quien se le encomienda determinar en el pleito existente entre los vecinos de Ceclavín y el comendador de Peñafiel sobre el derecho de los primeros a que sus ganados pastasen en el término de La Zarza. El alcalde mayor ampara a los vecinos de Ceclavín y dictamina que los vecinos de La Zarza y Peñafiel puedan hacer lo mismo con sus ganados en el término de Ceclavín, señalando a ambas partes hasta dónde podían llegar ${ }^{126}$. Y de Alfonso Martínez de Medina, bachiller en Leyes y alcalde mayor de la provincia de Castilla de la Orden de Santiago. Alfonso Martínez de Medina es uno de los destinatarios de una carta del maestre de esa orden, en la que les da a conocer la querella que había presentado el concejo de la Mesta, ya que cuando los ganados pasaban por los puertos para ir a los extremos los arrendadores y cogedores del servicio y montazgo, que pertenecía a dicha orden, les hacían pagar el rebujal por cada hato de 500 ó 600 cabras, para que no volviesen a contarlo otra vez y para que cesaran los cohechos de los arrendadores que a cada hato de ganado le imponían dos o tres florines ${ }^{127}$. Aunque en este caso quien dictamina es el propio maestre, como en el que antes enfrentó a Caravaca y Cehegín por cuestión de términos ${ }^{128}$.

123. Para los tratadistas del siglo XV había tres formas de alcanzar la nobleza: el ejercicio de las armas, las responsabilidades de gobierno y los títulos conseguidos en la Universidad.

124. Todo esto es un extracto que procede de lo escrito por Rodríguez Blanco 1991, pp. 440-441.

125. RAH., Col. Salazar y Castro, D-10, s/f. y M-5, ff. 76r-77v.

126. Lo cita Torres y Tapia 1999, p. 215; publicado en Colección diplomática 2000, n. ${ }^{\circ} 783$, pp. $542-543$.

127. AHN., Mesta, leg. 89, n. $^{\circ} 9$.

128. Publicado con la referencia de AHN., Consejos, leg. 11.537, n. ${ }^{\circ}$ 510, por Sáez 1946, pp. 131-135 y, como procedente del Archivo Municipal de Mula, sin signatura, por Torres Fontes 1982a, n. ${ }^{\circ} 20$, pp. $163-169$. 


\section{EN EL REGIMIENTO DE CIUDADES Y VILLAS}

Alejada, por lo general del entorno cortesano, convertido en coto casi exclusivo de la alta nobleza, la media y baja nobleza castellana se centrará en las ciudades, villas y lugares de su ámbito de influencia. Contaba para ello con disposiciones de carácter legal como el Ordenamiento de Alcalá promulgado por Alfonso XI o, en fechas de la minoría de Juan II, con alguna de las ordenanzas que el infante don Fernando había dado para su gobierno a las ciudades de Sevilla, Toledo y Cuenca. Estas normas legales sancionaban la aristocratización de los regimientos. Sin embargo, y derivado de ello se dieron otras circunstancias que favorecieron su implantación, una de las más importantes, sin duda, fue la de los vínculos feudovasalláticos que le unían a los linajes de la alta nobleza. En efecto, algunos de estos linajes trataban de controlar de forma directa o indirecta a los concejos de importantes ciudades del reino, baste citar los ejemplos de Sevilla, Murcia y Cuenca. Precisamente, los linajes de la nobleza media y baja fueron el instrumento utilizado, en algunos casos, por los grandes para a través o mediante ellos seguir ejerciendo su influencia en los gobiernos municipales. En cualquier caso, instrumentos en manos de los grandes o por su propia iniciativa, ejerciendo oficios ciudadanos o excluidos de ellos, estos miembros de la nobleza repitieron los mismos esquemas de comportamiento que se observa en los grandes y que abarcan entre otros la formación de bandos, la patrimonialización de los oficios de regimiento y la anexión de términos.

\subsection{Los bandos ${ }^{129}$}

Sobre los bandos nobiliarios en las ciudades de Sevilla, Murcia y Cuenca se han dado diversas interpretaciones. Desde que fueron consecuencia de la trasposición de las tensiones existentes en la corte, hasta la defensa de las libertades de la ciudad frente a las apetencias del centralismo regio, sin olvidar aquellas que encuentran su raíz en las carencias del sistema político y en el carácter banderizo del ejercicio del poder, o de que fueron consecuencia de un acto puntual como el hecho de Tordesillas.

El fenómeno de los bandos no se ciñe hoy a una lucha internobiliaria, sino que, al menos en el ámbito vasco se tiende a insertar en el de las luchas sociales bajomedievales, por lo que sus protagonistas fueron no solo los Parientes mayores ${ }^{130}$,

129. Para tener una visión general y completa de la extensión de este fenómeno en la Corona de Castilla y sus implicaciones es necesaria la consulta de varios artículos de Ladero Quesada 1991a, pp. 105-130; 1991b, pp. 105-134, y en menor medida en 1986, pp. 560-565.

130. El vocablo Parientes Mayores “... se refería a una categoría social construida para diferenciar un estado principal y una condición superior. Un criterio instituido en el seno de la práctica societaria empleada en la estructuración de los vínculos sociales. Y utilizado para producir y reproducir el conjunto trabado de relaciones y ligaduras elaboradas entre los hombres de aquella Tierra". Martín Paredes 1998, p. 208. Según Aguinagalde 1998, p. 152, las listas que se siguen utilizando para establecer el número de linajes de Parientes Mayores son, además de Lope García de Salazar, las del 
sino también los campesinos, los ferrones o los artesanos de las villas ${ }^{131}$. Desde esta perspectiva la imagen clásica de la lucha de bandos como un conflicto limitado a unos años y a una serie de hechos de armas, de batallas y quemas de villas, de terror rural, de enfrentamientos personales, de lucha entre jefes de bandos por motivos de honra o de "valer más", de manifiestación de un espíritu de clan y de deterioro de una manera violenta de solucionar los conflictos ${ }^{132}$, ha quedado superado. Pero esta visión de lucha social que es evidente en el área citada, entre otras razones por una perspectiva temporal más amplia que la que aquí se ha tomado como referencia, no resulta tan clara para los años de la minoría de Juan II y para otras zonas del reino de Castilla. En cualquier caso, lo que parece evidente es que la formación de bandos, parcialidades, "ajuntamientos", facciones, etc., por parte de la nobleza no tenía que ser un hecho excepcional en la vida política ciudadana, sino todo lo contrario como atestiguan la sentencia del maestre don Lorenzo Suárez de Figueroa entre el condestable Dávalos y Murcia en $1409^{133}$, una provisión del Consejo Real de Juan II al concejo de Madrid con ocasión de la elección de sexmeros ${ }^{134}$, otra del infante don Enrique maestre de Santiago dirigida al comendador de Mérida, en la que también se señala una de las causas que podían dar lugar a ello, la elección de oficios para el concejo ${ }^{135}$, o el juramento de Pedro López Dávalos ante el concejo de Murcia que, ante el requerimiento de imparcialidad, se compromete a no tomar bando ${ }^{136}$.

Aunque la división en bandos de la nobleza salmantina se constata en 1390, momento en que Juan I concede a la ciudad las Ordenanzas de Sotos Albos, por las que se regula el reparto de los cargos municipales entre los bandos de Santo Tomé y San Benito, no supondrá el fin de los enfrentamientos ${ }^{137}$. Durante la minoría

bachiller Zaldibia, de mediados del siglo XVI, y la que proporciona Lope Martínez de Ysasti en 1625. De acuerdo con ellos se habla de veinticinco linajes de Parientes Mayores.

131. Díaz de Durana Ortiz de Urbina 1998, p. 41, entre las propuestas que establece está la de entender la lucha de bandos en sentido amplio, en referencia a un conjunto de enfrentamientos sociales que se dieron en el territorio vasco en el marco de la ofensiva señorial durante la Baja Edad Media. Veánse también de Díaz de Durana Ortiz de Urbina 1999, pp. 154-170, y 2000, pp. 52-53. Por su parte, González Mínguez 1999, pp. 207-208, cuando trata de la renovación historiográfica de la lucha de bandos señala los trabajos de Fernández de Pinedo 1975, pp. 29-42, y de García de Cortazar y Ruiz de Aguirre 1975, pp. 283-313. El primero trató de situar la lucha de bandos en el marco general de la situación económico-social que atravesó Europa a lo largo de los siglos XIV y XV, y el segundo ve los acontecimientos banderizos "... como resultado de la hostilidad del mundo burgués en ascenso contra el antiguo mundo feudo-señorial en retroceso".

132. La relación procede de Aguinagalde 1998, pp. 159-160.

133. AMM., Cartulario Real 1491-1412, ff. 76v-81v, publicado por Cascales $1980^{4}$, pp. 241-243; por Ruano Prieto 1904, n. ${ }^{\circ}$ III, pp. 405-408; y por Cerdá Ruiz-Funes 1987, apéndice II, pp. 210-217; regesto en Pérez Bustamante y González de la Vega 1976, vol. II, n. ${ }^{\circ}$ 477, p. 200.

134. AVM.,-S 2-447-12, publicado por Millares Carlo 1943, vol. II, n. ${ }^{\circ}$ XVII, pp. 57-62; regesto en Cayetano Martín 1991, p. 85.

135. RAH., 9/5574, f. 247r-v. E1 22 de julio de 1417 se alcanzó un acuerdo de reparto riguroso de los oficios del concejo que se mantuvo muchos años, como tomo de Gerbet 1986, p. 564.

136. AMM., Actas Capitulares (1417 enero 10), f. 76r-v.

137. López Benito 1983, p. 66. Rucquoi, 1984, p. 46, destaca que los dos linajes llevasen el nombre de las dos parroquias donde se reunían. Mientras que Ladero Quesada 1991a, p. 119, indica que el bando de Santo Tomé fue de tradición realista, mientras que el de San Benito fue partidario de 
de Juan II, en concreto en 1410, se fecha el inicio de la división en bandos de la nobleza de la ciudad que alcanzará un gran auge en las tercera y cuarta décadas. En efecto, en la fecha citada ocurrió el asesinato de dos nietos de Fernán Rodríguez de Monroy, nacidos de su hija doña María de Monroy la Brava, que fueron muertos por los Manzanos en Salamanca, y cuya madre tomó venganza de ellos pasando a Viseo en el reino de Portugal donde estos últimos se habían refugiado asesinándolos ${ }^{138}$. Sin embargo, los bandos en la ciudad del Tormes tuvieron una vertiente no por más desconocida menos importante y fue su traslación al ámbito universitario. En efecto, conocemos que los bandos ciudadanos se enfrentaron, al menos en 1418, con motivo de la provisión de la cátedra de prima de Leyes ${ }^{139}$.

Más pacífica parece que era la situación de Ciudad Rodrigo, donde a comienzos de siglo -1401- el condestable Dávalos pronunció la sentencia que apaciguó durante un tiempo a los bandos que existían en la ciudad, al imponer la división de los oficios concejiles en tres partes Garci López, Pacheco y hombres buenos puestos por Enrique III ${ }^{140}$. No obstante en 1414 los dos linajes de la ciudad se comprometían a respetar el reparto igualitario de los oficios municipales, mayores y menores, entre ambos ${ }^{141}$.

En Andalucía la zona jiennense también nos proporciona ejemplos de ciudades en las que los bandos se convirtieron en uno de los rasgos de su vida política. Uno de ellos es Úbeda, ciudad en la que sus hidalgos estaban divididos entre los Trapera y los Aranda desde mediados del siglo XIV hasta aproximadamente $1406^{142}$. En la cercana Baeza, al igual que ocurrió en Salamanca años antes, la muerte de un noble caballero, Juan Fernández de Fuenmayor en 1417, fue el inicio de los

los infantes de Aragón hasta 1445, después del infante don Alfonso y de su hermana doña Isabel, que fue reina.

138. Así lo recoge Fernández 1627, de Bernardo Dorado. También se encuentra en el Memorial Histórico Español vol. VI, 1853, pp. 17-19. Este caso y otros que se pueden ver en Lope García de Salazar referidos al ámbito vasco tienen las mismas características que señala para la vendetta Heers 1978, pp. 130-131, sobre todo. A saber, vengar la muerte de una persona era un acto de deferencia y respeto hacia su memoria; de no hacerlo, ésta quedaría mancillada y, con ella, toda la estirpe, lo más frecuente es que la familia ofendida trate de aplicar la ley del talión, la venganza puede llevarse a cabo de maneras muy extrañas; cualquier ocasión sería propicia, sobre todo las que presentan un riesgo menor y permiten permanecer en el anonimato, en ocasiones el vengador tarda varios años, la venganza aboca inevitablemente a la guerra privada, pues la solidaridad de los clanes entra en juego. Por su parte, Mackay 1991b, pp. 18-19, lo pone como ejemplo del proceso de formación cultural, referido tanto a hechos auténticos como mitos, que constituían la historia y la mentalidad colectiva de un linaje o bando.

139. Val Valdivieso 1989, p. 220.

140. Bernal Estévez 1981, pp. 159-161; Hernández Vegas 1982, p. 230. Ladero Quesada 1991a, pp. 118-119, lo pone como ejemplo de la existencia de bandos linaje en las villas de las Extremaduras.

141. AMCRo., leg. 287, publicado por Barrios, Monsalvo Antón, Ser Quijano 1988, n. ${ }^{\circ}$ 77, pp. 138-141, regesto en la Colección diplomática 2000, n. ${ }^{\circ} 796$, p. 551. Monsalvo Antón 2008, pp. 185188, y en 2009, p. 206. Por su parte, Mackay 1991a, p. 511, destaca que los enfrentamientos entre los dos bandos de una ciudad "... ayudaban a reforzar el monopolio político urbano compartido por los enfrentados".

142. Rodríguez Molina 1991, p. 538. El linaje de los Aranda fijaría su residencia en Alcalá la Real en 1407, donde el condestable Dávalos los proveyó de oficios y honores, según Guardia Castellano 1913, p. 131. Por otro lado, los Aranda de la época de nuestro estudio y anteriores eran caballeros de la Banda, como pone de manifiesto Albarracín Navarro 1996, pp. 27-28. 
bandos, aunque no se desarrollaron hasta $1437^{143}$. La estrategia que el infante don Fernando utilizó para que esos ejemplos no se extendieran a la ciudad de Jaén fue destinar a la zona fronteriza con el reino de Granada a Luis López de Mendoza frontero en Bedmar y a Pedro Sánchez de Berrio en todo el obispado de Jaén ${ }^{144}$.

En Cantabria se produjeron luchas nobiliarias, en el valle de Carriedo se enfrentaron los del bando de Arce y los del bando de Avizondo en $1420^{145}$. No obstante, según el relato de Lope García de Salazar la zona oriental de esta región más cercana a la zona vasca fue la más afectada.

De donde contamos con más noticias sobre este fenómeno es del área vasca, donde se han ocupado de él autores como Lope García de Salazar que, junto a la documentación relativa a las villas y ya publicada, se ha convertido en una fuente primordial para su estudio, así como historiadores de siglos que van desde el XVI al XX y otros de época actual. A los numerosos artículos en revistas especializadas, congresos, simposios o reuniones, hay que sumar las monografías. De ahí que, nuestra intención no vaya más allá de una aproximación a un fenómeno que hunde sus raíces muy atrás y que se extiende por un periodo posterior al que aquí se trata ${ }^{146}$.

El fenómeno de los bandos en la zona castellano-navarra o, para ser más exactos, en ciertas áreas de ella, adquiere connotaciones de política exterior, por la intervención de nobles, sobre todo guipuzcoanos, en el área fronteriza con el reino de Navarra. En la gestación de los bandos se observan fenómenos tales como la desmovilización militar de parte de la nobleza, mucha de la cual había estado al servicio del reino de Navarra durante la segunda mitad del siglo XIV y hasta el primer tercio del siglo $\mathrm{XV}^{147}$, o la incorporación de la nobleza rural a la vida ciudadana, como ocurrió en Vitoria con los Ayala y los Iruña a finales del siglo

143. Cózar Martínez 1884, p. 262. Pareja Barranco 1987, pp. 130-131, y p. 152. Basándose en el primer autor también lo afirma Carmona Ruiz vol. II, 1997, p. 1304.

144. Porras Arboledas 1988, p. 32. El mismo autor inserta las biografías de estos dos personajes en 1990, pp. 274-276, y 287-289, correspondientes, respectivamente, a Luis López de Mendoza y a Pedro Sánchez de Berrio. En 1997, p. 204, señala que Luis López de Mendoza controló el concejo y los alcázares de Jaén durante estos años de comienzos del siglo XV. Por Ladero Quesada 1998, p. 536, conocemos que Luis López de Mendoza estaba vinculado al grupo Trapera-La Cueva.

145. Ortiz Real 1985, p. 122.

146. La bibliografía es amplísima, valgan como ejemplos, además de los que se citan refiriéndose al texto, los de Martínez de Ysasti 1625; Labayru y Goicoechea vol. III, 1968; Zumalde 1972, pp. 359-403; Banús y Aguirre 1975, pp. 65-81; Monreal y Cía 1975; Vadaurrázaga e Inchausti vol. VI, 1975; Aguirre Gandarías 1992, pp. 61-77; Díaz de Durana Ortiz de Urbina 1998, pp. 21-46. Sin embargo, donde se contiene amplia información bibliográfica y donde remitimos es al artículo de Lema Pueyo 1998, pp. 557-601, que organiza su trabajo exponiendo las ediciones de documentos, obras clásicas, estudios y monografías hasta 1940, estudios y monografías desde 1941 hasta la actualidad, e historias de localidades. Dacosta Martínez 1999a, pp. 57-70, de quien no hemos podido consultar 2004.

147. Fernández de Larrea y Rojas 1998, pp. 264-277, distingue cinco fases: 1265-1350, 1350$1363 ; 1364-1367 ; 1368-1395$ y 1406-1433. En la última señala que las relaciones entre la monarquía navarra y la nobleza guipuzcoana fueron más restringidos que durante la segunda mitad del siglo XIV. El mismo autor en 2000 , p. 25, lo circunscribe al periodo que va desde mediados del siglo XIV hasta los primeros años del siglo Xv. 
XIV y comienzos del $\mathrm{XV}^{148}$. Mendía y Elejalde menciona otros factores que favorecieron el surgimiento y propagación de los bandos, serían “... la constante guerra existente con los moros... la falta de fraternidad de los distintos linajes; el deseo de dominar unos sobre otros... contribuyendo además notablemente la poca influencia del poder de los Reyes"149. No obstante, se han apuntado otras razones como la idea de valer más ${ }^{150}$, la existencia de un importante grupo de pequeños nobles con una débil base económica, que tenían que “... competir por un territorio reducido no únicamente entre ellos sino también con una densa red de villas cada vez más poderosa y mejor organizadas" ${ }^{151}$. Así pues, las causas propias de la coyuntura del reino o intrínsecas al carácter de la nobleza ${ }^{152}$ no son más que algunas de las muchas a que obedecería un agravamiento de esta cuestión que alcanzó uno de sus momentos culminantes durante la minoría de Juan II, con dos fases críticas, la primera de 1410 a 1415 y la segunda de 1420 a $1426^{153}$.

Unos pocos casos, organizados desde un punto de vista geográfico, nos pueden servir para comprender la extensión y gravedad del problema y algunos de los medios puestos para controlarlo o impedirlo. Por ejemplo, en 1411 se trabó una pelea en Bilbao que duró varios días y en la que se enfrentaron los de Avendaño y los de Leguizamón contra los de Arbolancha, los de Asúa, los de Susunaga y los de Guecho. Contando ambos bandos con la ayuda de los de Butrón, Salazar, Gamboa y Arteaga, lo que motivó la intervención del "Doctor Gonsalo Moro [que hizo] treguas del Rey e esparsieronse todos a sus comarcas"154. En 1413 se produjo la lucha entre los de Leguizamón y los de Zurbarán que pelearon en el cantón de la Tendería de Bilbao ${ }^{155}$. Sin embargo, no era un problema que afectara únicamente a la villa de Bilbao, había otras integrantes de la actual provincia de Vizcaya en las que también se registraron manifestaciones de la violencia bande-

148. Portilla Vitoria vol. I, 1978, p. 102. En el mismo sentido se pronuncia Ladero Quesada 1991a, p. 114, que señala que la emigración de hidalgos rurales hacia la ciudad y hacia otras villas de Álava se produjo entre la disolución de la cofradía de Arriaga en 1332 y el primer cuarto del siglo XV.

149. Mendía y Elejalde 1994, p. 82.

150. La idea de quién valía más lo que quería era dar medida de la pujanza de los linajes, y según Arocena Echeverría 1959, p. 61, cuando lo señala Lope García de Salazar lo hace refiriéndose a los términos "hombres" y "rentas".

151. Fernández de Larrea y Rojas 2000, p. 43.

152. En su estudio sobre la violencia como forma del comportamiento nobiliario Gibello Bravo 1999, pp. 166-167, señala entre las inherentes a la nobleza: la educación recibida, la agresividad, la forma habitual de la vida nobiliaria, la diversión que suponían los ejercicios basados en la fuerza, la posibilidad de demostrar públicamente la posesión del poder mediante el abuso del mismo, la dificultad que tenían los segundones para acceder a unos niveles de riqueza análogos a los que habían gozado en la casa paterna y el aferramiento a sus medios de vida, que le hacen mostrarse reacia a buscar medios alternativos que le permitan la obtención de bienes.

153. Fernández de Larrea y Rojas 2000, p. 27.

154. García de Salazar vol. IV, 1967, pp. 187-188. De una edición anterior de este autor lo toman Echegaray 1895, p. 166, y Guiard y Larrauri vol. I, 1971, p. 94 (Edición Facsímil de la publicada en Bilbao, 1905). García Fernández 2007, p. 543.

155. García de Salazar vol. IV, 1967, pp. 188-189. De una edición anterior de este autor lo toma Echegaray vol. I, 1895, p. 167. Los dos ejemplos citados también los recoge Basas y Fernández 1975, p. 132. 
riza. En los años que nos ocupan Lequeitio, Valmaseda y Munguía, son algunos ejemplos ${ }^{156}$.

En el territorio de Álava la evolución de los bandos y del gobierno urbano ofrece trazos parecidos a los de Vizcaya y Bilbao ${ }^{157}$. Allí los linajes de Ayala y Avendaño se disputaron el señorío sobre el valle de Orozco en $1412^{158}$, y los Murgas asesinaron al arcipreste de Quejana en $1420^{159}$.

En Guipúzcoa destacamos el enfrentamiento entre los de la villa de Rentería y los del solar de Ugarte en 1413, motivado porque Juan de Gamboa expulsó de esa villa a Martín Sánchez de Ugarte y le tomó la prebostad de ella ${ }^{160}$. Y en 1420 la pendencia que protagonizaron Fernando de Gamboa y todos los gamboínos al quemar la casa de Unzueta y a doce hombres dentro de ella ${ }^{161}$.

Los ejemplos señalados, una mínima parte de los que expone Lope García de Salazar, reflejan como los episodios de violencia banderiza formaron parte de un fenómeno de carácter general en el que el territorio más afectado durante la minoría de Juan II fue el de Vizcaya. De la atenta lectura de la obra de este autor, para el periodo señalado, también se llega a la conclusión de que hubo rivalidades permanentes o, al menos, muy duraderas entre linajes ${ }^{162}$, aunque también se dieron casos, los menos, en que esas rivalidades finalizaron a raíz de una tregua o por acuerdos de carácter matrimonial. La implicación de algunos linajes en estos enfrentamientos no se circunscribía a su área de predominio, sino que a veces se extendía a los territorios vecinos, bien porque tuvieran en ellos intereses de algún tipo ${ }^{163}$, por los vínculos que mantenían con otros linajes y que les obligaban a ayudarles, por cobrar honra, fama y botín o por venganza. Llama la atención que de los denominados Parientes mayores ninguno perezca en los combates, sí algún heredero que lo debía ocupar ${ }^{164}$, casi todos los que mueren son integrantes de grados más bajos de

156. Los tres los expone de forma correlativa García de Salazar vol. IV, 1967, pp. 189-193. Las banderías de Vizcaya se caracterizan por su generalidad y por su duración, como indica Ladero Quesada 1991a, p. 114.

157. Ladero Quesada 1991a, p. 114.

158. García de Salazar vol. IV, 1967, pp. 254-255. De una edición anterior de esta obra y referido a Martín Ruiz de Avendaño lo recoge de Guerra 1930, pp. 8-9. Mendía y Elejalde 1994, pp. 88-89. García Fernández 2007, p. 542.

159. García de Salazar vol. IV, 1967, pp. 265-266. Basándose en una edición anterior de esta obra y referido a Juan Yarzu de Salcedo véase de Guerra 1930, p. 187.

160. García de Salazar vol. IV, 1967, pp. 254-255. De una edición anterior de esta obra y referido a Martín Ruiz de Avendaño véase de Guerra 1930, pp. 8-9.

161. García de Salazar vol. IV, 1967, p. 174. Basándose en una edición anterior de esta obra y referido a Fernando de Gamboa lo recoge de Guerra 1930, p. 83.

162. Como habría ocurrido entre los Legizamón y los Zurbarán que estuvieron enfrentados más de veinte años. García de Salazar vol. IV, 1967, p. 188.

163. ¿Pudo tener alguna influencia el patronazgo que ejercían sobre monasterios e iglesias? Aunque los casos de los linajes de Arteaga, Avendaño, Butrón, Múgica, Salazar y Yarza parecen limitarse al territorio de la actual provincia de Vizcaya, algunos de ellos tenían derechos de patronazgo a veces bastante alejados y que en ocasiones coincidían desde un punto de vista geográfíco con los de otro linaje o que estaban dispersos en varios núcleos. Al respecto, véase Dacosta Martínez 1999b, p. 39, sobre todo, donde inserta un mapa de las áreas de influencia de los principales linajes.

164. García de Salazar vol. IV, 1967, p. 189, muerte de Rodrigo Adán de Yarza, “... njeto eredero de Adan de Yarça, con vna saeta por los pechos". 
la nobleza ${ }^{165}$. En todas estas peleas hay muertes, generalmente causadas por armas como las ballestas y también hay casos de violencia extrema con la amputación de miembros ${ }^{166}$. Las manifestaciones de esta violencia no afectaron únicamente a villas importantes - caso de Bilbao, por ejemplo- u otras que en aquellos momentos serían de carácter menor ${ }^{167}$, sino que muchos de los ataques se centraron en la casa solar del linaje contrario ${ }^{168}$ y en torres-fortaleza o casas fuertes ${ }^{169}$.

En total son cuarenta y tres episodios violentos los que hemos cuantificado y que, como puede verse, se distribuyen sobre todo entre 1410 y 1420 . En esos años los tres picos más elevados se alcanzan en 1413, 1415 y 1420, separados por otros de menor intensidad en 1414, 1416 y 1419. Respecto a los linajes más conocidos que aparecen mencionados en más ocasiones por su intervención en ellos encontramos a los Avendaño en 1411 y 1412, a los Gamboa en 1413, 1414 y 1420 y a los Salazar en 1413, 1416 y 1417, por citar a algunos. De cualquier manera, resultan bastante extraños esos bruscos ascensos y caídas y dan pie a pensar que García de Salazar hizo una selección de los que, por la razón que fuere, le interesaron más ${ }^{170}$.

Entre los más afectados por toda esta situación de violencia se encontraban las villas ${ }^{171} \mathrm{y}$, por supuesto, sus vecinos, a algunos de los cuales los nobles ban-

165. Por ejemplo, la muerte de Rodrigo de Sagarminaga en 1414. García de Salazar vol. IV, 1967, p. 189.

166. Un ejemplo en el que se recoge lo expresado fue el de Pedro Çorrilla al que mataron los ballesteros, a decir de García de Salazar, con treinta y cinco saetas y al que después cortaron la cabeza. García de Salazar vol. IV, 1967, p. 384.

167. Mungía, donde se enfrentaron Gonzalo Gómez de Butrón y Juan de Avendaño en 1414. García de Salazar vol. IV, 1967, pp. 191-193. O Portugalete donde varios linajes se pelearon en 1417. García de Salazar vol. IV, 1967, p. 362.

168. Aunque la quema de la casa de Marzana ocurrió en 1387 un nieto del titular de entonces renuncia a la querella presentada contra el concejo de Mondragón, contra otros concejos de la Hermandad de Guipúzcoa y contra “... los caudillos e señores e otras personas que acaescieron en la dicha tala e quema", a fecha de 28 de noviembre de 1410. Colección de documentos inéditos para la Historia de Guipúzcoa 1, San Sebastián, 1958, pp. 17-22. García de Salazar vol. IV, 1967, p. 174, da cuenta de la quema de la casa de Unzueta. Véase también Lema Pueyo 2002, p. 65, que pone de manifiesto que en 1410 aún no se había resuelto el pleito.

169. Juan de Avendaño quemó la casa fuerte que Juan de Múgica poseía en Ochandiano en mayo de 1415. García de Salazar vol. IV, 1967, pp. 194-195. Las torres-fortaleza y casas-fuertes fueron un factor de poderío, tanto en la ciudad como en el campo, servían como lugar de refugio, al permitír al linaje defenderse de sus enemigos, y como hábitat. Véase al respecto el estudio que hace de las torres Heers 1978 , pp. 204-232, pues aunque se centra especialmente en Italia y en Francia algunas de sus apreciaciones son válidas para el caso hispano.

170. No hay que olvidar lo que toma Dacosta Martínez 1998, p. 130, de Sabino Aguirre Gandarias, biógrafo de Lope García de Salazar, de que éste trata tanto de glorificar el propio linaje como de "aleccionar a los suyos". Por su parte, Díaz de Durana Ortiz de Urbina 2001, pp. 253-254, en la misma línea señala que Lope García de Salazar “... utilizó la narración para justificar sus acciones como Pariente Mayor y trasladar a sus descendientes la memoria de su linaje”. Al respecto puede verse el artículo de Beceiro Pita 1990, pp. 329-349.

171. Como ha observado Val Valdivieso 1985, p. 331, en la extensión del conflicto banderizo al interior de las villas se mezclan, en ocasiones, tanto las luchas por el poder entre los miembros de las oligarquías urbanas como las resistencias de carácter antiseñorial. 
derizos habían desafiado ${ }^{172}$. Los bandos también fomentaron la delincuencia en ciertas áreas como la limítrofe con el reino de Navarra, la "... frontera de los malhechores"173. Violencia a la que se trató de poner freno con la entrega a las autoridades de uno y otro reino de los que entraban en ellos a cometer algún delito y que después de haberlos perpetrado se pasaban al suyo donde eran protegidos por los nobles de la tierra ${ }^{174}$. Esta parece haber sido la razón aparente, aunque no la única ${ }^{175}$, que dio lugar a la constitución de las Hermandades. Por ejemplo, la hermandad que existía en Vizcaya desde 1397 y que seguía vigente en $1408^{176} \mathrm{o}$ de la que a instancias de Vitoria, Treviño y Salvatierra se hizo en $1417^{177}$ y que no parece que cumpliera con sus objetivos de poner orden en la tierra y acabar con los malhechores ${ }^{178}$. Desde un punto de vista económico la inestabilidad generada por las continuas luchas de bandos provocó una dilapidación de recursos, como suponían la destrucción de cosechas, ferrerías, asaltos a viandantes y a mercaderes $^{179}$. En ciertas poblaciones, como Vitoria, las luchas de bandos provocaron un estancamiento económico ${ }^{180} \mathrm{o}$, cuando menos, la detención transitoria de su desa-

172. Los Avendaño y algunos de sus parientes habían desafiado hacia 1413 a los vecinos de la villa de Segura. AMSeg., B/1/1/22/, publicado por Salazar Fernández 1993, n. ${ }^{\circ} 136$, pp. 119-121.

173. Mugueta Moreno 2000, p. 50, señala entre otras razones, que los linajes oñacinos con claros intereses en los pastos de Urbasa-Andía, Burunda y Aralar, vieron cortadas sus posibilidades económicas en estas zonas por la progresiva afirmación de esta frontera y su incipiente delimitación, a esto se suma la unión de bandoleros navarros "encartados o acotados".

174. AGN., Comptos, cajón 100, n. ${ }^{\circ}$ 33, regesto en Castro vol. XXIX, 1962, n. ${ }^{\circ}$ 120, pp. 73-74. González Mínguez 1982, p. 445, también cita y transcribe alguna línea de este documento y lo publica Orella Unzué 1985, apéndices 3, pp. 487-488.

175. Moreta Velayos 1978, pp. 176-177, se hace eco de las dos interpretaciones de la historiografía sobre las causas que dan origen a las hermandades. La liberal-burguesa del siglo XIX y comienzos del XX que veía a las hermandades como “... ligas o confederaciones organizadas con la finalidad de hacer frente a la violencia y opresión de los "poderosos de la tierra"”, y la que parte de las afirmaciones de Luis Suárez Fernández, en "Evolución histórica de las hermandades castellanas" que afirma que la “... causa inmediata que produjo el nacimiento de la Hermandad... es la debilidad, más temporal que permanente de la monarquía”. Suárez Fernández 1951, p. 5.

176. AMLeq., reg. 14, n. ${ }^{\circ}$ 24, publicado por Enríquez Fernández, Hidalgo de Cisneros Amestoy, Lorente Ruigómez y Martínez Lahidalga 1992, n. ${ }^{\circ}$ 49, pp. 113-115.

177. APÁl., D-171-5, publicado por Iñurrieta Ambrosio 1983, n. ${ }^{\circ}$ 10, pp. 22-23, que recoge también otras publicaciones que habían editado antes el citado documento como, por ejemplo González de Echevarri vol. III, 1901, pp. 311-318, y Martínez Díez vol. II, 1974, pp. 247-254. Con otra signatura lo cita Landázuri Romarate, 1930, pp. 84-85. También se encuentra en la RAH., 9/5464, Landázuri y Romarate vol. II, s/a, s/1, cap. 9, ff. 90-92. Véase también González Mínguez vol. I, 1997, pp. 599-601, sobre todo.

178. González Mínguez 1982, pp. 446 y 448.

179. Monreal y Cía 1975 , p. 87.

180. En las peticiones que los cabildos de artesanos de la ciudad de Vitoria envían al rey y que servirán de base para las ordenanzas de 1423 se contiene lo siguiente: “... considerando que por los males de nuestros pecados e por ocasión e causa de los Vandos de Aiala e Calleja que de presente an sido e son en la dicha villa, muy amenudo entre los homes que quieren vivir en paz sosiego por bandera los unos a los otros se perece la justicia de nro. Señor el Rey e vienen escandalos e muertes e lesiones de los homes e se pierden los homes e por no andar los homes seguros en su mercaderias e negocios por miedo de sus cuerpos por no poder travajar en sus labores e oficios e vanse los homes desamparando la dicha villa a vivir a otras partes del reino de Navarra e de Aragon e de otras partes por las quales razones viene al rey gran despoblamiento e destruimiento desta villa". Así lo toma de la obra 
rrollo ${ }^{181}$. Mientras que desde una óptica institucional los bandos profundizaron la brecha que separaba a las villas de la Tierra Llana ${ }^{182}$.

\subsection{La patrimonialización de los oficios}

Igual que la alta nobleza, cuyos miembros ejercían distintos oficios públicos y cortesanos y lograron hacerlos hereditarios en sus descendientes, los niveles inferiores de ese estamento social ostentaron buena parte de los oficios de ámbito local, a veces por delegación de los grandes, contribuyendo a la aristocratización de los regimientos y a mantener dichos oficios y cargos en su linaje ${ }^{183}$. En uno y otro caso los oficios eran creados y cubiertos por el monarca ${ }^{184}$, aunque aquí nos ocupemos solo de los conferidos por éste tras la renuncia previa de un pariente, y que tuvieron lugar durante la minoría de Juan II de Castilla ${ }^{185}$. Los escasos ejemplos que se exponen a continuación no nos permiten afirmar que la práctica de la renuncia estuviese bastante extendida en estos momentos, lo que parece estar fuera de toda duda es su normal aceptación.

En ese contexto los oficios de regimiento ciudadano fueron unos de los más apetecidos ${ }^{186}$. En algunas villas como Ciudad Rodrigo, apoyándose en sus privilegios, su ordenamiento jurídico preveía que quedando vacante el oficio por renuncia o muerte de su titular se eligiera dentro del propio linaje, bien por los regidores del concejo o por la mayor parte ${ }^{187}$.

En ese sentido nos han llegado varias concesiones en las que consta la intervención de Juan II en la provisión de oficios. Valgan como ejemplos para el ámbito andaluz los de Rodrigo Cerón, regidor de Baeza en lugar de su padre, Pedro Ruiz difunto, en marzo de 1411 188; Fernán Ruiz Cabeza de Vaca de un oficio de

de Fray Juan de Victoria, De la antigüedad de España y naciones cántabras y nobleza suya, publicada parcialmente por Vidaurrazaga e Inchausti, 1975, pp. 163-164; Díaz de Durana Ortiz de Urbina 1984, pp. 59-60. Las ordenanzas de 1423 las ha publicado Díaz de Durana Ortiz de Urbina 1982, apéndice documental, n. ${ }^{\circ} 1$, pp. 489-500.

181. González Mínguez 1980, pp. 192-200.

182. Monreal y Cía 1975 , p. 85 .

183. Tomás y Valiente 1970, pp. 125-159. Como tomamos del profesor Ladero Quesada 2014, p. 385 “... el acaparamiento de la administración municipal jugó un papel capital en la formación y delimitación de una nobleza media”.

184. Fraga Iribarne y Beneyto Pérez vol. I, 1964, p. 408, que además señalan la identificación que había en la Edad Media entre orden social y orden político.

185. Excluímos de este trabajo aquellos que se produjeron en años anteriores y posteriores a los aquí considerados, de los que encontramos ejemplos en publicaciones muy diversas como Sánchez Saus 1996.

186. Ladero Quesada 1973, pp. 38-41, basándose en las páginas que Ortiz de Zúñiga dedica a los componentes del concejo de Sevilla de 1410, da cuenta de hasta dieciocho linajes de la media y baja nobleza que integraban dicha institución. Algunos de estos nobles habían heredado el cargo de sus antepasados y otros lograron transmitirlo a sus descendientes.

187. AMCRo., leg. 287, publicado por Barrios, Monsalvo Antón y del Ser Quijano 2000, n. ${ }^{\circ}$ 796, p. 551. Monsalvo Antón 1990, pp. 375-376; Monsalvo Antón 2008, pp. 185-188. Sobre los regidores, su condición, orígenes, evolución y competencias véase Cerdá Ruiz-Funes 1970, pp. 180-187, en especial.

188. González Jiménez 1990, n. ${ }^{\circ}$ 80, p. 98. De quien lo toma González Sánchez 2012, p. 127. 
regimiento y trecenazgo en Jerez de la Frontera, que su padre había renunciado en él en vida ${ }^{189}$; Pedro de Pineda, escribano mayor del concejo de Sevilla, cargo que había renunciado en él su suegro Bernal González ${ }^{190}$; Pedro de Ribera al que el rey hizo merced de una veinticuatría, por muerte de su padre, casi con toda seguridad el 23 de noviembre de 1407, pues es a partir de esta fecha cuando el mayordomo del concejo debía de pagarle lo que le correspondiese de su salario ${ }^{191}$, o Pedro Fernández, oficial del cuchillo e hijo de Diego Fernández, que sustituía a su padre el mariscal en el oficio de alguacil mayor de la ciudad de Córdoba -al igual que éste había sustituido a su padre Gonzalo Fernández-, al que cual había renunciado, traspasado a su hijo y pedido al rey que le hiciese esta merced. El rey manda al concejo de la ciudad de Córdoba que lo aceptasen, excepto si era clérigo de corona, y que una vez hecho el juramento le entregasen la cárcel o cárceles de dicha ciudad, las cadenas, prisiones y todas las otras cosas anejas al dicho oficio, como las llaves de todas las puertas de Córdoba ${ }^{192}$.

Sin que conste expresamente la intervención regia, precisamente en Sevilla ${ }^{193}$ y al frente de una de las alcaldías mayores de la ciudad Juan Fernández de Mendoza sucedió a su padre Diego Fernández de Mendoza, muerto hacia $1411^{194}$. Alfonso de las Casas que fue alcaide de la fortaleza de Cañete y fiel ejecutor de Sevilla, cargo con el que se le compensarían sus ocupaciones militares durante las campañas granadinas, también debió de traspasar el oficio a su hijo Guillén, que ya lo desempeñaba en $1421^{195}$. Lope Ortiz de Stúñiga que fue guarda mayor de Enrique III también fue alcalde mayor de Sevilla desde 1410, por la muerte de Lope Ortiz, su primo segundo. Ambos tuvieron el cargo en representación de Pedro de Stúñiga, hijo del justicia mayor, al que le correspondía por su suegro ${ }^{196}$, lo que revela entre otras cuestiones las conexiones entre la alta nobleza y la de rango medio $^{197}$. Lorenzo García de Cáceres dejó a su hijo Fernán al frente de la alcaidía de Villanueva del Camino, en 1410, y a su hijo Álvar sustituyéndole en una vein-

189. AMJeF., Actas Capitulares (1410), ff. 3v-4r, regesto por Abellán Pérez 1990, n. ${ }^{\circ}$ 1, p. 137, y publicado por el mismo en 2011, n. 3, pp. 93-94. La fecha de concesión es de 14 de marzo de 1409, ejemplo que también recoge González Sánchez 2012, p. 127. Referencias a este oficio y a este personaje en Orellana González 2015, pp. 99, 101, 102. Véase también Ruiz Pilares 2010-2012, pp. 67-77.

190. Collantes de Terán Delorme 1980, n. ${ }^{\circ}$ 51, p. 40, con fecha 15 de febrero de 1419. Sabemos que Bernal González fue encarcelado junto con su mujer por orden del rey, en relación con la administración de los bienes recaudados para la campaña de Antequera. Así lo toma del autor citado Cabrera Muñoz 1994, p. 29. Véase también Pardo Rodríguez (2000), p. 360.

191. Collantes de Terán Delorme 1972, n. ${ }^{\circ} 132$, p. 229.

192. Biblioteca Zabálburu, Sección Altamira, carp. 13, n. 3 (29 marzo 1420).

193. Sobre la aristocracia sevillana de esta época véase Sánchez Saus 2005, pp. 15-44 y 45-68.

194. Sánchez Saus 1991, p. 195; Sánchez Saus 2009, p. 54.

195. Sánchez Saus 1991, p. 68.

196. Ibídem, p. 293.

197. Son muchos los ejemplos de lugartenencia que se pueden poner y que afectaron a distintos niveles de la nobleza y a todo tipo de oficios, como los relacionados con el regimiento, los hacendístico-fiscales o los militares. Ejemplo del primero son los de Ruiz Gutiérrez de Parras, lugarteniente de Diego Fernández, mariscal de Castilla y alguacil mayor de Córdoba que había sido nombrado para este último cargo en 1410, como se contiene en AHMCo., Caja 19, n. ${ }^{\circ} 2$ (1410, enero 21); Esteban Fernández Machuca, lugarteniente por Pedro López de Ayala, alcalde mayor de Toledo, RAH., Salazar 
ticuatría de Sevilla ${ }^{198}$. Un caso parecido encontramos en Juan Rodríguez de Hoyos quien renunció en su hijo y homónimo una veinticuatría a su muerte en $1407^{199}$. Con quien surgen ciertas dudas es con Fernando Pérez de Villafranca, mayordomo del concejo sevillano entre 1388 y 1389 , que tuvo como lugarteniente a su yerno Sologrús Bocanegra que llegó a ser veinticuatro de Sevilla en 1414, si bien parece que en su nombramiento concurrieron otras causas ${ }^{200}$.

Al margen de los oficios de regimiento también hubo casos de renuncias y concesiones de tenencias de fortalezas y de cargos de lo que podríamos denominar administración territorial. En la persona de Lope de Alarcón se dieron estas circunstancias pues, con fecha 10 de julio de 1419, Juan II le concedía la tenencia de la fortaleza de la villa de Alarcón y la merindad de la villa de Iniesta y de su tierra, que su padre Martín Ruiz de Alarcón había renunciado en él ${ }^{201}$.

Esta consideración de los oficios como instrumentos de medro, primero personal y después familiar al hacerlos hereditarios, supondrá la consolidación económica, social y política de la nobleza media y baja ${ }^{202}$. En muchos casos, el desempeño de esos cargos por medio de lugartenientes o la consideración de los oficios como mercedes por parte de algunos monarcas despojará a los oficios de su contenido práctico.

\subsection{La usurpación de tierras y las disputas de términos}

La usurpación de términos fue una más de las injerencias de la nobleza en la vida municipal ${ }^{203}$. Se sumaba a las mediatizaciones ya señaladas o a las que llevaba a cabo en las rentas de la corona o en los bienes de los monasterios e iglesias de la zona donde estaba asentada.

Sobre esta cuestión nos han llegado testimonios de varios procesos emprendidos por la ciudad de Ávila y los pueblos de su tierra contra diversos miembros de la nobleza sobre ocupaciones de términos o de propiedades que estos habían realizado ${ }^{204}$. A comienzos de enero de 1414 el concejo de Ávila y los pueblos de

y Castro, O-6. Fols. 73v-74v (1410 agosto 19); o de carácter militar Fernán Ruiz Cabeza de Vaca, lugarteniente del almirante Alfonso Enríquez, como tomo de Calderón Ortega 2003, nota 357, p. 79.

198. Sánchez Saus 2009, p. 85.

199. Ibídem, p. 98.

200. Sánchez Saus 1991, p. 52 y 2009, p. 95. En esta última publicación se pone de manifiesto que pudieron ser determinantes en este nombramiento sus servicios a la corona como "tesorero mayor de la guerra”, p. 125. Sobre Sologrús Bocanegra véase el trabajo de Cañas Gálvez (2017), pp. 193-212.

201. “... por quanto el dicho vuestro padre renunçió en vos la dicha merindad e me pidio por merçed que vos fesiese merçed della; e por esta mi carta mando al conçejo e alcaldes e otras justiçias e ofiçiales e omes buenos qualesquier de la dicha villa de Yniesta e de su tierra,... que vos ayan por mi merino de la dicha villa e en su tierra en lugar del dicho vuestro padre". Lasso de la Vega 1945, n. ${ }^{\circ}$ XIII, pp. 43-44 y n. ${ }^{\circ}$ XIV, pp. 45-45. Sobre ambos personajes véase Ortega Cervigón 2006, pp. 196-197.

202. Sánchez Saus 2012, p. 369, considera la hereditariedad de los oficios como una muestra del triunfo de la mentalidad nobliaria entre los patriciados urbanos.

203. Véanse, para época posterior a la que aquí se estudia los artículos de Diago Hernando (2009), pp. 229-240, y García Oliva (2017), pp. 157-178.

204. Sobre esta problemática, ámbito y época, Monsalvo Antón, (2001), pp. 89-122. 
su tierra tenían abiertos varios procesos contra Catalina González, que pretendía mantener el desvío que había realizado su marido en el cauce del antiguo arroyo que pasaba por Flores, aldea de Ávila y la ocupación de las riberas del mismo ${ }^{205}$. Contra Diego González del Águila sobre la posesión del echo ${ }^{206}$ de Villacarlón, que éste tenía ocupado, sobre la dehesa de Villaviciosa y sobre los lugares de Albornos, Naharros y Gallegos ${ }^{207}$. Y contra Juan de Contreras sobre la ocupación del término de Garganta de Gallegos, próximo a Riofrío ${ }^{208}$. Estas apropiaciones motivaron el envío de un juez comisario, cargo que recayó en Nicolás Pérez alcalde de Segovia ${ }^{209}$ que, en los casos citados, dictaminó a favor de Ávila y de los pueblos de su tierra.

Las ocupaciones ilegales debieron proseguir o, al menos, los procesos judiciales se resolvieron más tarde, entre otras razones, sin duda, estaría una que el testigo de uno de los procesos reconoce en la declaración que hace ante el juez, donde expresa, refiriéndose a las ocupaciones de Diego González del Águila, que se produjeron “... porque era hombre poderoso e que los labradores de la comarca con miedo que non osaron demandarlo" ${ }^{210}$. Sin duda, tampoco hay que olvidar que en esta pugna entre el concejo de Ávila y su tierra, por un lado, y la nobleza territorial, por otro, ésta última se vio favorecida por el enorme alfoz que la primera tenía que administrar ${ }^{211}$ y por el incremento de la potencia nobiliaria.

Estas circunstancias y otras más contribuyeron a que el número de ocupaciones, apropiaciones y disputas por la tierra fuera elevado. Así, tenemos constancia de que a mediados de agosto de 1415 el citado Nicolás Pérez dictamina sobre las ocupaciones de términos que había realizado Pedro González de Ávila de tierras, pinares y pastos que pertenecían a los concejos de Burgohondo, Navalmoral, El

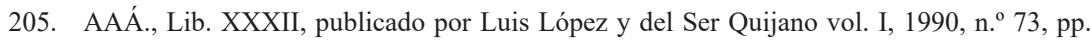
$208-227$.

206. Los echos son espacios acotados para la ganadería, sobre los que trata en el ámbito gaditano Martín Gutiérrez 2015, pp. 47-70, sobre todo.

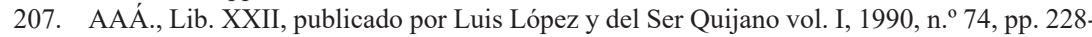
283. También cita este documento y esta obra Monsalvo Antón 1997, nota 98, p. 319 y en 2002, p. 155.

208. AAÁ., Lib. XXIV, publicado por Luis López y del Ser Quijano vol. I, 1990, n. ${ }^{\circ} 77$, pp. 341 368. Los casos de Catalina González, Diego González del Águila y el de Juan de Contreras, además de estudiados, están recogidos en el cuadro de usurpaciones de Ávila y su tierra que inserta en su estudio Monsalvo Antón 2010, p. 175. Este autor, basándose en los documentos, recoge una serie de abusos, violencias y coacciones de los caballeros denunciadas en sus procesos judiciales, como se puede ver en las pp. 139-140.

209. Aparte de los casos citados conocemos que se le prorrogó en su cometido al menos dos veces, la primera debió ser con fecha 16 de marzo de 1415, cuando Juan II desde Valladolid la amplía por seis meses, y la segunda fechada el 11 de marzo de 1416, también en Valladolid, cuando el monarca se la prórroga por cuatro. AAÁ., libs. I, ff. 1-4 y II, ff. 48v-50, publicados por Luis López y del Ser Quijano vol. I, 1990, n. ${ }^{\circ} 84$, pp. 378-383 y n. ${ }^{\circ}$ 99, pp. 429-432.

210. AAÁ., Lib. XXII, publicado por Luis López y del Ser Quijano vol. I, 1990, n. ${ }^{\circ} 74$, pp. 228-283.

211. Precisamente en alguno de los alejados límites se produjeron ocupaciones de términos a la jurisdicción de Ávila, por ejemplo, algunos colindantes con el de Cantaracillo, aldea de Ávila por parte del concejo de Peñaranda de Bracamonte. AAÁ., Lib. II, publicado por Luis López y del Ser Quijano vol. I, 1990, n. ${ }^{\circ} 92$, pp. 401-419. 
Barraco, El Helipar y Quintanar de la Tierra de Ávila ${ }^{212}$. En el mes de noviembre del citado año se resuelve el proceso judicial entre la ciudad y Tierra de Ávila y Diego de Contreras, cuya madre Urraca González había ocupado la dehesa de Avellanosa, situada en el término de San Miguel de la Serrezuela, en relación con la cual el juez comisario confirma los mojones antiguos y ordena derribar los que se habían hecho nuevos, declarando que dicha dehesa era término común de Ávila.

De los casos expuestos no se deduce el predominio de un tipo concreto de bien susceptible de apropiación, aunque llaman la atención varias de las ocupaciones de dehesas, ¿quiere eso decir que los nobles implicados se habían especializado en la ganadería y con ello pretendían incrementarla y, por consiguiente, allegar más ingresos? Sencillamente lo desconocemos, al igual, y es posible que así fuera, que esas propiedades y términos que ocupan estuviesen cerca de las suyas.

El fenómeno estaba extendido por otras partes de Castilla tan distantes entre sí como el obispado de Calahorra, Ciudad Rodrigo, Trujillo o Córdoba. En el primero la intensificación de las cargas por parte de los hidalgos, usurpando tierras y bienes comunales a los municipios, provocó que las Constituciones Sinodales del obispado, aprobadas en 1410, determinaran la excomunión de los escuderos y de otros que tomaban las décimas, tercias y derechos de los clérigos ${ }^{213}$. En Ciudad Rodrigo el corregidor, Gómez Arias, a petición del procurador y sexmeros de la villa, ordena que se reintegre como devaso junto a la dehesa de Medinilla lo ocupado por Sancho Gómez y sus herederos en el lugar de Alba de Yeltes y en Fuentes de Oñoro, a finales de mayo y a comienzos de junio de $1414^{214}$. En Trujillo los campesinos de la villa se quejaban al rey de la apropiación abusiva de las tierras comunitarias por parte de los oficiales del concejo - por otra parte señorializado-, con fecha 7 de diciembre de $1417^{215}$. En Córdoba se dio un caso bastante parecido durante los años de la minoría de Juan II, se trataba de Diego Ferrández de la Trinidad, veinticuatro de la ciudad y posiblemente cuarto hijo del mariscal de Castilla Diego Fernández de Córdoba. Diego Ferrández de la Trinidad era uno de los mayores propietarios en los términos de Hinojosa y Gahete hacia 1420. Parte de esas tierras las había recibido en herencia y otras muchas las había usurpado como denuncian los oficiales de Gahete al concejo de Córdoba ${ }^{216}$. En esta última ciudad y aunque no se responsabiliza a nadie en concreto, en la protesta de los jurados ante los alcades mayores, alguacil y veinticuatros se les pide que hagan "... tornar

212. AMNSi., s/sig, publicado por Luis López 1987, pp. 57-58.

213. Así lo toma Fernández de Pinedo 1560, f. LXv.

214. AMCRo., leg. 303 (leg. 20, n. ${ }^{\circ}$ 23) y leg. 303 (leg. n. ${ }^{\circ}$ 20, n. ${ }^{\circ}$ 5), publicados por Barrios, Monsalvo Antón y del Ser Quijano 1988, n. ${ }^{\circ} 73$, pp. 130-134 y n. ${ }^{\circ} 74$, pp. 134-137. Véase también Luchía (2008), pp. 284 y 288.

215. Procedente de Gerbet 1979, p. 439, lo recoge Fernández-Daza Alvear 1991, p. 250.

216. Cabrera Muñoz vol. I, 1978, pp. 54-55. La denuncia sobre las usurpaciones efectuadas en el término de Gahete procede del AMCó., Sección 19, Ser. 19, n. ${ }^{\circ}$ 3, y está publicada en el apéndice documental n. ${ }^{\circ}$ 1, p. 63. Este autor establece una tipología que se divide en usurpaciones y abusos en tierras señoriales y en tierras de realengo. En el primer caso esas usurpaciones podían ser sobre tierras baldías, bienes de propios y bienes de particulares. Mientras que en las tierras de realengo solo recoge los de tierras. Además, estarían las compras ilegales de tierras y las usurpaciones de jurisdicción. 
a Cordova las tierras que le son tomadas" 217 , no obstante, por una queja anterior, se acusa a los poderosos de tener "... tomadas non debidamente muchas tierras del término desta dicha cibdat et que las avolvieron a otras sus heredades"218.

\section{CONCLUSIÓN}

En los casos de la media y baja nobleza castellana y salvando las distancias se observa que sus ámbitos de actuación, modos de comportamiento e intereses son similares de los de la alta nobleza del reino. En tal sentido y en orden a una mayor transparencia hemos dividido sus actuaciones en tres vertientes. La primera la militar, destacando que en conjunto conocemos relativamente poco de esta faceta durante los años de nuestro estudio. Para ello se han tenido en consideración las campañas militares contra el reino de Granada, las operaciones que facilitaron al infante don Fernando el trono de la Corona de Aragón y la implicación de esos miembros de la media y baja nobleza castellana en los bandos ciudadanos y sus enfrentamientos armados.

Durante la campaña de 1407 la media y baja nobleza castellana figura en un papel subordinado a los grandes personajes de la alta nobleza. Al finalizar esa campaña solo algunos de entre ellos logran alcaidías en algún castillo frontero. En el periodo de treguas que le sucedió ciertos personajes de este grupo nobiliario llevaron la iniciativa en las incursiones al reino nazarí, sin duda como medio de afirmación y como vía de promoción. En la campaña de 1410 la actuación de la media y baja nobleza también sería de carácter secundario, siempre y al igual que en el caso anterior, según las crónicas. En tal sentido se les encomiendan las tareas de aprovisionamiento, son compañía de los grandes en las operaciones militares y en las correrías fronterizas, siendo excepcionales las referencias al valor demostrado o a la muerte.

Más importante sin duda fue el papel que algunos integrantes de esa media y baja nobleza tuvieron durante el interregno en la Corona de Aragón (1410-1412) $\mathrm{y}$, sobre todo, durante el asedio a Balaguer, momento en el que, al margen de sus acciones de armas, en las que debieron de participar más de cuatrocientos, alguno de ellos estuvo entre los consejeros del monarca.

Las luchas banderizas de ciudades y comarcas castellanas también contaron con la participación de la media y baja nobleza, entre otras razones, por sus vínculos con los grandes linajes que encabezaban esos bandos y que en números casos les utilizan como fuerza de choque. En algunas ciudades como, por ejemplo, Murcia o en el ámbito vasco o en Galicia, en que el peso de esa media y baja nobleza es cuantitativamente importante, su implicación será mayor o menor en los citados bandos.

La presencia de la media y baja nobleza en las órdenes militares fue cuantitativamente muy importante, en ellas ejercieron cargos de nivel medio, como los de

217. Mazo Romero 1978, n. ${ }^{\circ}$ 1, p. 104.

218. Nieto Cumplido 1982, p. 32. 
comendador o clavero y aspiraron incluso al maestrazgo. En este sentido, y hasta después de la muerte de Fernando de Antequera en 1416, esa opción se reveló imposible, como demuestra el caso de Fernández de Villagarcía. Las órdenes militares sirvieron a la Corona, al alto clero y a la alta nobleza para recompensar a sus peones, segundones en ciertos casos, con cargos que les reportaban un importante poder y sustanciosos ingresos. Algunos de esos casos, al menos cinco, se refieren en el texto. Además, les facilitarían consolidarse en ámbitos locales y regionales donde ya tenían fijados sus intereses, aunque no se ha documentado ningún caso de comendadores que tuviesen un señorío propio y la encomienda de una orden militar durante este periodo.

Se destaca sobre todo el potencial estático de las órdenes militares en los ámbitos fronterizos portugués y granadino, donde poseían numerosas encomiendas; mientras que contamos con problemas para demostrar el potencial militar efectivo que tenían por la carencia de datos o por su carácter fragmentario para los años de nuestro estudio.

Durante la minoría de Juan II de Castilla y el maestrazgo de don Lorenzo Suárez de Figueroa al frente de la orden de Santiago se observa una modificación importante en la relación entre maestre y comendadores y entre estos y los concejos de las órdenes con la introducción de los alcaldes mayores, cargos ocupados principalmente por letrados, debido a su preparación intelectual.

Los integrantes de la media y baja nobleza sirvieron a los grandes para a través de ellos seguir ejerciendo su influencia en los gobiernos de ciudades y villas, repitiendo algunos de sus comportamientos.

Así, por ejemplo, la formación e implicación de este grupo de la nobleza en los bandos ciudadanos fue bastante frecuente durante los años que abarca este estudio, aunque en algunos casos procedan de años anteriores: Salamanca, Ciudad Rodrigo, Úbeda, valle de Carriedo en Cantabria y el ámbito vasco, son alguno de ellos. Precisamente del ámbito vasco es de donde contamos con más información sobre este fenómeno, que se incrementó entre 1410 y 1415, por lo que aquí respecta. Bilbao fue una de las poblaciones más afectadas y, en menor medida, Álava y Guipúzcoa. Siguiendo a Lope García de Salazar hemos contabilizado cuarenta y tres episodios de violencia banderiza durante los años de la minoría de Juan II. Esta situación de gran inseguridad motivó, entre otras medidas, la formación de la Hermandad de 1417 entre Vitoria, Treviño y Salvatierra.

La nobleza media y baja trató de patrimonializar los oficios públicos traspasándolos a algunos de sus herederos, así como la tenencia de fortalezas y cargos de lo que podemos entender como administración territorial. Esto supuso la consolidación económica, social y política de este grupo nobiliario.

La usurpación de términos fue una más de las injerencias de la nobleza media y baja en la vida municipal. Se sumaba a las mediatizaciones ya señaladas o a las que llevaba a cabo en las rentas de la Corona o en los bienes de los monasterios e iglesias de la zona donde estaba asentada. Sobre esta cuestión nos han llegado testimonios de varios procesos emprendidos por la ciudad de Ávila y los pueblos de su tierra contra diversos miembros de la nobleza sobre ocupaciones de términos 
o de propiedades que estos habían realizado. No obstante, el fenómeno se extendía por otras partes de Castilla tan distantes entre sí como el obispado de Calahorra, Ciudad Rodrigo, Trujillo o Córdoba, por citar unos casos.

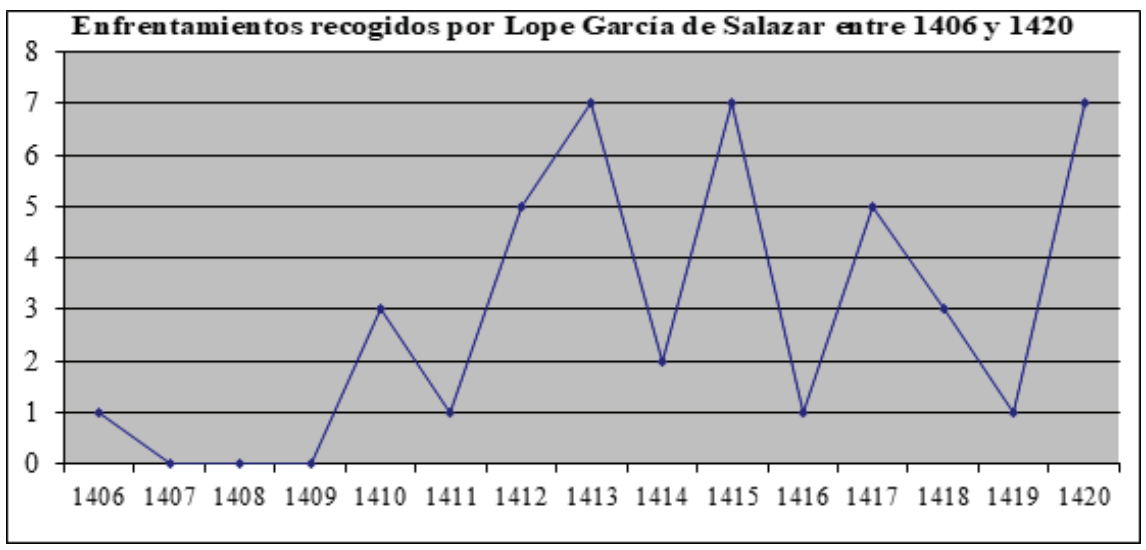

\section{BIBLIOGRAFÍA}

(1560), Constituciones synodales del Obispado de Calahorra y La calzada... con acuerdo del sínodo que... se celebró en la Ciudad de Logroño, de 1533, León.

(1853), Memorial Histórico Español: colección de documentos, opúsculos y antigüedades, que publica la Real Academia de la Historia, vol. VI, Madrid.

(1958), Colección de documentos inéditos para la Historia de Guipúzcoa 1, San Sebastián.

(1970) As Gavetas da Torre do Tombo. VIII. (Gav. XIII-XIV), Lisboa.

(1988), Colección diplomática medieval de Alcalá la Real. I. Transcripción de los documentos, Alcalá la Real.

(2000), Colección diplomática medieval de la Orden de Alcántara (1157?-1494), Bonifacio Palacios Martín (dir), Madrid.

Abellán Pérez, Juan (1990), El Concejo de Jerez de la Frontera en la primera mitad del siglo $X V$ : composición, sistemas de elección y funcionamiento del cabildo, Jerez de la Frontera.

Abellán Pérez, Juan (2011), Diplomatario del reino de Granada. Documentos de Juan II de Castilla (1407-1454) del Archivo Municipal de Jerez de la Frontera, Granada.

Abellán Pérez, Juan (2016), "Entre la historia y la leyenda: el lance de los cuatro juanes (1409)", Estudios sobre Patrimonio, Cultura y Ciencias Medievales, 18, pp. 69-80.

Aguado de Córdova, Francisco Antonio, Alemán y Rosales, Alfonso Antonio y López Urguleta, José (1719), Bullarium equestris ordinis S. Iacobi de Spatha, Madrid. 
Aguinagalde, F. Borja de (1998), "La genealogía de los Solares y Linajes guipuzcoanos bajomedievales. Reflexiones y ejemplos", Lucha de bandos en el País Vasco: de los Parientes mayores a la Hidalguía Universal. Guipúzcoa, de los Bandos a la Provincia (ss. XIV a XVI), José Ramón Díaz de Durana Ortiz de Urbina (ed.), Bilbao, pp. 148-206.

Aguirre Gandarias, Sabino (1992), "Bizkaia medieval en defensa de su fuero", Cuadernos de Sección. Historia y Geografía, 19, pp. 61-77.

Albarracín Navarro, Joaquina (1996), "La Orden de la Banda a través de la Frontera Nazarí", Estudios de Frontera. Alcalá la Real y el Arcipreste de Hita, (Francisco Toro Ceballos y José Rodríguez Molina, coords.), Jaén, pp. 17-30.

Álvarez de Morales, Antonio (1985), "La evolución de las Hermandades en el siglo XV”, En la España Medieval. La ciudad hispánica durante los siglos XIII al XVI, I 6, pp. 93-103.

Aponte, Vasco de (1986), Recuento de las Casas antigüas del Reino de Galicia, Santiago de Compostela.

Arco y Molinero, E. (1899), Glorias de la nobleza española, s/l.

Argente del Castillo, Carmen (1991), La ganadería medieval andaluza. Siglos XIII-XVI. (Reinos de Jaén y Córdoba), vol. I.

Aroncena Echevarría, Ignacio (1959), Oñacinos y gamboínos. Introducción al estudio de la guerra de bandos, Pamplona.

Arquellada, Juan de (1996), Anales de Jaén, Estudio, edición y notas por Manuel González Jiménez, Granada.

Ayerbe Iríbar, María Rosa (1985), Historia del Condado de Oñate y señorío de los Guevara (s. XI-XVI), Guipúzcoa.

Banús y Aguirre, José Luis (1975), "Los banderizos. Interpretación étnica y geopolítica", La sociedad vasca rural y urbana en el marco de la crisis de los siglos XIV y XV, Bilbao, pp. 65-81.

Barrios, Ángel, Monsalvo Antón, José María y Ser Quijano, Gregorio del (1988), Documentación medieval del Archivo Municipal de Ciudad Rodrigo, Salamanca.

Basas y Fernández, Manuel (1975), "La institucionalización de los Bandos en la Sociedad Bilbaína y Vizcaína al comienzo de la Edad Moderna", La sociedad vasca rural y urbana en el marco de la crisis de los siglos XIV y XV, Bilbao, pp. 115-160.

Beceiro Pita, Isabel (1990), "La conciencia de los antepasados y la gloria del linaje en la Castilla bajomedieval", Relaciones de poder, de producción y de parentesco en la Edad Media y Moderna. Aproximación a su estudio, Reyna Pastor (compiladora), Madrid, pp. 329-349.

Bernal Estévez, Ángel (1981), Ciudad Rodrigo en la Edad Media, Salamanca.

Cabrera Muñoz, Emilio (1978), "Usurpación de tierras y abusos señoriales en la sierra cordobesa durante los siglos XIV y XV", Actas del I Congreso de Historia de Andalucía. Andalucía Medieval, vol. I, Córdoba, pp. 33-83. 
Cabrera Muñoz, Emilio (1987), "Los señoríos de Extremadura durante el siglo XV”, Hernán Cortés y su tiempo. Actas del Congreso Hernán Cortés y su tiempo V Centenario (1485-1985), Mérida, pp. 132-145.

Cabrera Muñoz, Emilio (1994), "Crimen y castigo en Andalucía durante el siglo XV”, Meridies, 1, pp. 9-37.

Calderón Ortega, José Manuel (2003), El Almirantazgo de Castilla: Historia de una institución conflictiva (1250-1560), Alcalá de Henares.

Cañas Gálvez, Francisco de Paula (2017), “Algunos apuntes sobre micer Salagrús Bocanegra, tesorero mayor de la guerra de moros y escribano de las armadas del rey. Logística económica y militar en la frontera de Granada (1388†1425)", Frontera y fortificación, Enrique Martínez Ruiz, Jesús Cantera Montenegro y Magdalena de Pazzis Pi Corrales (Directores), Madrid, pp. 193-212.

Carmona Ruiz, María Antonia (1997), "Lucha de bandos en Baeza", La Península Ibérica en la época de los descubrimientos 1391-1492. Actas III Jornadas Hispano-Portuguesas de Historia Medieval, vol. II, Sevilla, pp. 1301-1307.

Caro de Torres, Francisco (1629), Historia de las órdenes Militares de Santiago, Calatrava y Alcántara desde su fundación hasta el Rey Don Filipe Segundo Administrador perpetuo dellas, Madrid.

Carramolino Martín, Juan (1872), Historia de Ávila, su provincia y obispado, vol. II, Madrid.

Cascales, Francisco de $\left(1980^{4}\right)$, Discursos históricos de la ciudad de Murcia y de su Reino, Murcia.

Castrillo Llamas, María Concepción (1997), La tenencia de fortalezas en la Corona de Castilla durante la Baja Edad Media, Tesis doctoral inédita, Universidad Complutense, vol. II, Madrid.

Cayetano Martín, María del Carmen (1991), La documentación medieval en el Archivo de Villa (1152-1474), Madrid.

Cerdá Ruiz-Funes, Joaquín (1970), “Hombres buenos, jurados y regidores en los municipios castellanos de la Baja Edad Media", Actas del I Symposium de Historia de la Administración, Madrid, pp. 161-206.

Cerdá Ruiz-Funes, Joaquín (1987), “Adelantados mayores y concejo de Murcia. (Notas para un estudio histórico-jurídico)", Estudios sobre instituciones medievales de Murcia y su Reino, Murcia, apéndice II, pp. 210-217.

Collantes de Terán Delorme, Francisco (1972), Archivo Municipal de Sevilla. Inventario de los papeles del Mayordomazgo del siglo XV, 1401-1416, vol. I, Sevilla.

Collantes de Terán Delorme, Francisco (1980), Archivo Municipal de Sevilla. Inventario de los papeles del Mayordomazgo del siglo XV, 1417-1430, vol. II, Sevilla.

Collantes de Terán y Caamaño, Francisco (1990), Historia de Morón de la Frontera, Biblioteca de Estudios Moroneses, Sevilla.

Corral Val, Luis (1999), Los monjes soldados de la orden de Alcántara en la Edad Media. Su organización institucional y vida religiosa, Madrid. 
Cózar Martínez, Fernando de (1884), Noticias y documentos para la historia de Baeza, Jaén.

Dacosta Martínez, Arsenio Fernando (1998), "Historiografía y Bandos. Reflexiones acerca de la crítica y justificación de la violencia banderiza en su contexto", La Lucha de Bandos en el País Vasco: de los Parientes Mayores a la Hidalguía Universal. Guipúzcoa, de los bandos a la Provincia (siglos XIV a XVI), José Ramón Díaz de Durana Ortiz de Urbina (ed.), Bilbao, pp. 121-148.

Dacosta Martínez, Arsenio Fernando (1999a), ““”De dónde sucedieron unos a otros". La historia y el parentesco visto por los linajes vizcaínos bajomedievales", Vasconia, 28, pp. 57-70.

Dacosta Martínez, Arsenio Fernando (1999b), "Patronos y linajes en el Señorío de Bizkaia. Materiales para una cartografía del poder en la baja Edad Media", Vasconia, 29, pp. 21-46.

Dacosta Martínez, Arsenio Fernando (2004), Los linajes de Bizkaia en la Baja Edad Media: poder, parentesco y conflicto, Bilbao.

Diago Hernando, Máximo (2009), "Las ocupaciones de términos en la tierra de Cuenca a fines de la Edad Media: algunas peculiaridades locales de una práctica generalizada en la Corona de Castilla", Castilla y el mundo feudal. Homenaje al profesor Julio Valdeón, M. a Isabel del Val Valdivieso y Pascual Martínez Sopena (Dirs.), vol. III, Valladolid, pp. 229-240.

Díaz Ballesteros, Miguel (1873), Historia de la villa de Ocaña, vol. II, Ocaña.

Díaz de Durana Ortiz de Urbina, José Ramón (1982), "La lucha de bandos en Vitoria y sus repercusiones en el concejo (1352-1476)", Vitoria en la Edad Media. Actas del I Congreso de Estudios Históricos celebrado en esta Ciudad del 21 al 26 de setiembre de 1981, en conmemoración del 800 aniversario de su fundación, Vitoria, pp. 477-500.

Díaz de Durana Ortiz de Urbina, José Ramón (1984), Vitoria a fines de la Edad Media (1428-1476), Vitoria.

Díaz de Durana Ortiz de Urbina, José Ramón (1998), "Historia y presente del tratamiento historiográfico sobre la Lucha de Bandos en el País Vasco. Balance y perspectivas al inicio de una nueva investigación", La Lucha de Bandos en el País Vasco: de los Parientes Mayores a la Hidalguía Universal. Guipúzcoa, de los bandos a la Provincia (siglos XIV a XVI), José Ramón Díaz de Durana Ortiz de Urbina (ed.), Bilbao, pp. 21-46.

Díaz de Durana Ortiz de Urbina, José Ramón (1999), “Luchas sociales y luchas de bandos en el País Vasco durante la Baja Edad Media”, Historiar, 3, pp. 154-170.

Díaz de Durana Ortiz de Urbina, José Ramón (2000), "Parientes mayores y señores de la Tierra guipuzcoana", Los señores de la guerra y de la tierra: nuevos textos para el estudio de los Parientes Mayores guipuzcoanos (1265-1548), José Ángel Lema Pueyo, Jon Andoni Fernández de Larrea Rojas, Ernesto García Fernández, José Antonio Munita Loinaz, José Ramón Díaz de Durana Ortiz de Urbina, San Sebastián, pp. 47-73. 
Díaz de Durana Ortiz de Urbina, José Ramón (2001), "Linajes y bandos en el País Vasco durante los siglos XIV y XV", La familia en la Edad Media. IX Semana de Estudios Medievales Nájera 2000, José Ignacio de la Iglesia Duarte (Coordinador), Logroño, pp. 253-284.

Echegaray, Carmelo de (1895), Las provincias Vascongadas a fines de la Edad Media, vol. I, San Sebastián.

Enríquez Fernández, Javier, Hidalgo de Cisneros Amestoy, Concepción, Lorente Ruigómez, Araceli y Martínez Lahidalga, Adela (1992), Colección documental del archivo municipal de Lequeitio. Tomo I. (1325-1474), San Sebastián.

Fernández de Larrea y Rojas, Jon Andoni (1998), "La participación de la nobleza guipuzcoana en la renta feudal centralizada: Vasallos y mercenarios al servicio de los reyes de Navarra (1350-1433)", La Lucha de Bandos, pp. 261-321.

Fernández de Larrea y Rojas, Jon Andoni (2000), "Los señores de la guerra en la Guipúzcoa bajomedieval”, Los señores de la guerra y de la tierra: nuevos textos para el estudio de los Parientes Mayores guipuzcoanos (1265-1548), José Ángel Lema Pueyo, Jon Andoni Fernández de Larrea Rojas, Ernesto García Fernández, José Antonio Munita Loinaz, José Ramón Díaz de Durana Ortiz de Urbina, San Sebastián, pp. 21-43.

Fernández de Pinedo, Emiliano (1975), “¿Lucha de bandos; o conflicto social?”, La sociedad vasca rural y urbana en el marco de la crisis de los siglos XIV y $X V$, Bilbao, pp. 29-42.

Fernández Izquierdo, Francisco (1986), "El régimen concejil de Almonacid de Zorita bajo el dominio de la Orden de Calatrava (siglos XIII-XVI)", Anuario de Estudios Medievales, 16, pp. 391-420.

Fernández, Alonso (1627), Historia y anales de la ciudad y obispado de Plasencia, Madrid.

Fernández-Daza Alvear, Carmen (1991), La ciudad de Trujillo y su tierra en la Baja Edad Media, Madrid.

Fraga Iribarne, Manuel y Beneyto Pérez, Juan (1964), "La enajenación de oficios públicos en su perspectiva histórica y sociológica", Centenario de la Ley del Notariado. Estudio Histórico, vol. I, Madrid, pp. 395-472.

Fuster Ruiz, Francisco (1978), Aspectos históricos, artísticos, sociales y económicos de la provincia de Albacete, Valencia.

García de Cortazar y Ruiz de Aguirre, José Ángel (1975), "El fortalecimiento de la burguesía como grupo social dirigente de la Sociedad Vascongada a lo largo de los siglos XIV y XV", La sociedad vasca, pp. 283-313.

García Oliva, María Dolores (2017), "Usurpaciones de tierras comunales en el término de Plasencia a fines de la Edad Media”, Studia Historica. Historia Medieval, 35/1, pp. 157-178.

García de Salazar, Lope (1967), Las bienandanzas e fortunas. Códice del siglo XV, Primera impresión del texto completo, con prólogo, notas e índices por Ángel Rodríguez Herrero, vol. IV, Bilbao. 
García de Santa María, Álvar (1972), Le parti inedite della: "Crónica de Juan II" di Álvar García de Santa María, Edizione critica, introduzione e note a cura di Donatella Ferro, Venezia.

García de Santa María, Álvar (1982), Crónica de Juan II de Castilla, Edición de Juan de Mata Carriazo y Arroquia, Madrid.

García Fernández, Ernesto (2007), "El linaje Avendaño: causas y consecuencias de su ascenso social en la Baja Edad Media", Anuario de Estudios Medievales, 37/2, pp. 527-561.

García Fernández, Ernesto (2009), "La Casa de Guevara en la Edad Media: poder y conflicto en las tierras de un linaje señorial", Castilla y el mundo feudal.

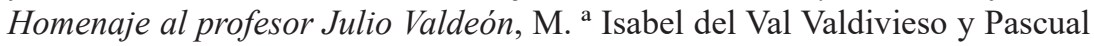
Martínez Sopena (Dirs.), vol. I, Valladolid, pp. 387-405.

García Vera, María José y Castrillo Llamas, María Concepción (1993), Nobleza y poder militar en Castilla a fines de la Edad Media", Medievalismo. Boletín de la Sociedad Española de Estudios Medievales, 3, pp. 19-37.

Garza Cortés, Rosario (1996), La villa de Estepa al final del dominio santiaguista, Estepa.

Gerbet, Marie Claude (1979), La noblesse dans le Royaume de Castille. Etude sur ses structures sociales en Estrémadure de 1454 à 1516, Paris.

Gerbet, Marie Claude (1986), "Essai sur 1'apparition d'une moyenne noblesse dans 1'Estremadure de la fin du Moyen-Age", Anuario de Estudios Medievales, 16, pp. 557-570.

Gerbet, Marie Claude (1989a), “Acces a la noblesse et renouvellement nobiliaire dans le royaume de Castille (de la Reconquête au XVe siècle)", Arquivos do Centro Cultural Portugués, XXVI, pp. 359-387.

Gerbet, Marie Claude (1989b), La nobleza en la Corona de Castilla. Sus estructuras sociales en Extremadura (1454-1516), Cáceres.

Gibello Bravo, Víctor M. (1999), La imagen de la nobleza castellana en la Baja Edad Media, Cáceres.

González de Echevarri, V. (1901), Alaveses ilustres, vol. III, Vitoria.

González Jiménez, Manuel (1987), "Morón de la Frontera a comienzos del siglo XV", Anuario de Estudios Medievales, 17, pp. 401-422.

González Jiménez, Manuel (1988), "Morón, una villa de frontera (1402-1427)", IV Coloquio de Historia Medieval Andaluza. Relaciones exteriores del Reino de Granada, Segura Graiño, Cristina (Ed.), Almería, pp. 55-70.

González Jiménez, Manuel (1990), "Documentos referentes a Andalucía en Nobleza de Andalucía de Gonzalo Argote de Molina", Historia. Instituciones. Documentos, 17, pp. 83-106.

González Jiménez, Manuel y García Fernández, Manuel (1992), Actas Capitulares de Morón de la Frontera (1402-1426), Sevilla.

González Mínguez, César (1980), "Cosas vedadas en Castilla y factores determinantes del desarrollo económico de Vitoria en la Baja Edad Media”, Boletín de la Institución Sancho el Sabio, Año XXIV, Tomo XXIV, pp. 177-231. 
González Mínguez, César (1982), "El movimiento hermandino en Álava”, En la España Medieval. Estudios en memoria del profesor D. Salvador de Moxó, vol. I, 2, pp. 435-456.

González Mínguez, César (1997), “Concejos, Cortes y Hermandades en la estructura de poder de la Corona de Castilla en los últimos siglos medievales: el caso de Álava", La Península Ibérica en la era de los descubrimientos 1391-1492. Actas III Jornadas Hispano-Portuguesas de Historia Medieval, vol. I, Sevilla, pp. 585-610.

González Mínguez, César (1999), "Linajes nobiliarios y luchas de bandos en el espacio vascongado", La nobleza peninsular en la Edad Media. VI Congreso de Estudios Medievales, León, pp. 197-225.

González Sánchez, Santiago (2012), “La intervención regia en el gobierno y la administración concejiles durante la minoría de Juan II de Castilla”, Estudios sobre Patrimonio, Cultura y Ciencias Medievales. In Memoriam del Dr. D. Manuel Riu, XIII-XIV, pp. 123-144.

González Sánchez, Santiago (2013), "La presencia de la media y baja nobleza en las Órdenes Militares durante la minoría de Juan II de Castilla", Revista de las Órdenes Militares. Homenaje al profesor don Eloy Benito Ruano, 7, pp. 57-70.

González Sánchez, Santiago (2017), “1413, el año inédito de la Crónica de Juan de Castilla de Álvar García de Santa María, del manuscrito 9-462 de la Real Academia de la Historia", Boletín de la Real Academia de la Historia, Tomo CCXIV/ II, pp. 213-278.

González Sánchez, Santiago, "La presencia de hombres de armas castellanos en el cerco a Balaguer, 1413" (en prensa).

Goñi Gaztambide, José (1965), "Los españoles en el Concilio de Constanza. Notas biográficas”, Hispania Sacra, XVIII pp. 103-158 y 265-332.

Guardia Castellano, Antonio (1913), Leyenda y notas para la historia de Alcalá la Real, Madrid.

Guerra, Juan Carlos de (1930), Oñacinos y Gamboínos. Rol de banderizos vascos, con la mención de las familias pobladoras de Bilbao en los siglos XIV y XV, San Sebastián.

Guiard y Larrauri, Teófilo (1971), Historia de la noble villa de Bilbao (13001600), vol. I, Bilbao (Edición Facsímil de la publicada en Bilbao, 1905).

Heers, Jacques (1978), El clan familiar en la Edad Media, Barcelona.

Hernández Vargas, Mateo (1982), Ciudad Rodrigo: la catedral y la ciudad, Ciudad Rodrigo.

Iñurieta Ambrosio, Esperanza (1983), Cartulario Real a la provincia de Álava (1258-1500), San Sebastián.

Juan Lovera, Carmen (1977), “Alcalá la Real, puerta a Granada de Castilla. Presentación de la Colección Diplomática Alcalaina”, Boletín del Instituto de Estudios Giennenses, año XXIII n. ${ }^{\circ}$ 91, pp. 9-45.

Labayru y Goicoechea, Estanislao (1968), Historia general del Señorío de Vizca$y a$, vol. III, Bilbao. 
Ladero Quesada, Manuel Fernando (1982), "La Orden de Alcántara en el siglo XV. Datos sobre su potencial militar, territorial, económico y demográfico", En la España Medieval. Estudios en memoria del profesor D. Salvador de Moxó, vol. I, 2, pp. 499-541.

Ladero Quesada, Miguel Ángel (1973), Andalucía en el siglo XV. Estudios de Historia Política, Madrid.

Ladero Quesada, Miguel Ángel (1986), "Corona y ciudades en la Castilla del siglo XV”, En la España Medieval. Estudios en memoria del profesor D. Claudio Sánchez-Albornoz, I V, pp. 551-574.

Ladero Quesada, Miguel Ángel (1991a), “Lignages, bandos et partis dans la vie politique des villes castillanes (XIV ${ }^{\mathrm{e}}-\mathrm{XV}^{\mathrm{e}}$ siècles)", Les sociétés urbaines en France méridionale et en Péninsule Ibérique au Moyen Âge, (Actes du Colloque de Pau, 21-23 septembre 1988), Paris, pp. 105-130.

Ladero Quesada, Miguel Ángel (1991b), "Linajes, bandos y parcialidades en la vida política de las ciudades castellanas (siglos XIV y XV)", Cuadernos de la Biblioteca Española. Bandos y querellas dinásticas en España al final de la Edad Media. Actas del Coloquio celebrado en la Biblioteca Española de París los días 15 y 16 de mayo de 1987, vol. I, París, pp. 105-134.

Ladero Quesada, Miguel Ángel (1998), "La Orden de Santiago en Andalucía. Bienes, rentas y vasallos a finales del siglo XV", Los señores de Andalucía. Investigaciones sobre nobles y señorios en los siglos XIII a XV, Cádiz, pp. 521-575.

Ladero Quesada, Miguel Ángel (2014), "La consolidación de la nobleza en la Baja Edad Media", Poder político y sociedad en Castilla. Siglos XIII al XV, Selección de estudios preparada con motivo de su jubilación como Catedrático de Universidad, Coordinador José Manuel Nieto Soria, Madrid, pp. 377-404.

Landázuri Romarate, Joaquín José de (1930), Historia civil, eclesiástica, política y legislativa de la M. N. y M. L. ciudad Vitoria, sus privilegios, esenciones, franquezas y libertades, deducida de memorias, y documentos auténticos, Vitoria.

Landázuri Romarate, Joaquín José de (s/a), Historia de Álava en Historia del muy Ilustre País Vascongado, vol. II, s/l.

Lasarte Cordero, Miguel (1956), "Alcaides y comendadores del castillo de Estepa", Archivo Hispalense, 78-79, pp. 101-122.

Lasso de la Vega, Miguel (Marqués de Saltillo) (1945), El Señorío de Valverde, Cuenca.

Lema Pueyo, José Ángel (1998), "La lucha de Bandos en el País Vasco. Bibliografía para su estudio", La Lucha de Bandos en el País Vasco: de los Parientes Mayores a la Hidalguía Universal. Guipúzcoa, de los bandos a la Provincia (siglos XIV a XVI), José Ramón Díaz de Durana Ortiz de Urbina (ed.), Bilbao, pp. 557-601.

Lema Pueyo, José Ángel (2002), "Por los procuradores de los escuderos hijosdalgo". De la Hermandad General a la formación de las juntas de la provincia de Guipúzcoa (siglos XIV-XVI)", El triunfo de las elites urbanas guipuzcoanas: 
nuevos textos para el estudio del gobierno de las villas de la Provincia (14121539), José Ángel Lema Pueyo... [et. al], San Sebastián, pp. 59-113.

Lera Maillo, José Carlos de, López Vallina, José Ramón, Lorenzo Pinar, Francisco J., Moreta Velayos, Salustiano y García Diego, Alberto (1998), Colección diplomática del Imperial monasterio de Nuestra Señora de Valparaíso (11431499), Zamora.

Lomax, Derek W. (1981), "La reforma de la Orden de Alcántara durante el maestrazgo del infante don Sancho, 1411-1413”, Anuario de Estudios Medievales, 11, pp. 759-773.

López Benito, Clara Isabel (1983), Bandos nobiliarios en Salamanca al iniciarse la Edad Moderna, Salamanca.

López Ferreiro, Antonio (1983), Historia de la Santa A. M. Iglesia de Santiago de Compostela, vol. VII, Santiago de Compostela, Facsímil de la de Santiago de Compostela, 1904).

Luchía, Corina (2008), "Los pleitos por los términos comunales en el concejo de Ciudad Rodrigo en la Baja Edad Media", Historia. Instituciones. Documentos, 35, pp. 269-290.

Luis López, Carmelo de (1987), "El proceso de señorialización en el siglo XV de Ávila. La consolidación de la nueva nobleza", Cuadernos Abulenses, 7, pp. 53-66.

Luis López, Carmelo de y Ser Quijano, Gregorio del (1990), Documentación medieval del Asocio de la Extinguida Universidad y Tierra de Ávila, vol. I, Avila.

Mackay, Angus (1991a), "La conflictividad social urbana", Actas del VI Coloquio Internacional de Historia Medieval Andaluza. Las ciudades andaluzas (siglos XIII-XV), Málaga, pp. 509-524.

Mackay, Angus (1991b), "Los bandos: aspectos culturales", Cuadernos de la Biblioteca Española. Bandos y querellas dinásticas en España al final de la Edad Media. Actas del Coloquio celebrado en la Biblioteca Española de París los días 15 y 16 de mayo de 1987, 1, pp. 15-27.

Martel, Miguel (1967), Canto tercero de "La Numantina" y su comento: de la fundación de Soria y origen de sus doce linajes, Madrid.

Martín Gutiérrez, Emilio (2015), Paisajes, ganadería y medio ambiente en las comarcas gaditanas. Siglos XIII al XVI, Cádiz.

Martín Paredes, José Antonio (1998), “QQué es un Pariente Mayor? El ejemplo de los señores de Oñaz y Loyola", La Lucha de Bandos en el País Vasco: de los Parientes Mayores a la Hidalguía Universal. Guipúzcoa, de los bandos a la Provincia (siglos XIV a XVI), José Ramón Díaz de Durana Ortiz de Urbina (ed.), Bilbao, pp. 207-233.

Martínez de Isasti, Lope (1625), Compendio historial de la Muy Noble y Muy Leal provincia de Guipúzcoa, San Sebastián.

Martínez Díez, Gonzalo (1974), Álava medieval, vol. II, Vitoria.

Mazo Romero, Fernando (1978), “Tensiones sociales en el municipio cordobés en la primera mitad del siglo XV", Actas del I Congreso de Historia de Andalucía. Andalucía Medieval, vol. II, Córdoba, pp. 85-112. 
Mazo Romero, Fernando (1980), El Condado de Feria (1394-1505). Contribución al estudio del proceso señorializador en Extremadura durante la Edad Media, Badajoz.

Menache, Sophie (1986), "La Orden de Calatrava y el clero andaluz (siglos XIIIXV)", En la España Medieval, V, pp. 633-653.

Mendía y Elejalde, Santiago (1994), El Condado de Ayala, Introducción Silvestre Portilla, Vitoria, (Facsímil de la edición de Vitoria, 1892).

Menjot, Denis (1991), "Hidalguía et caballería à Murcie: contours sociaux d'une aristocratie urbaine du XIII ${ }^{\mathrm{e}}$ au XV $\mathrm{XV}^{\mathrm{e}}$ siècle", Les societés urbaines en France méridonale et en Péninsule Ibérique au Moyen Âge. Actes du Colloque de Pau, 21-23 septembre 1988, Paris, pp. 219-227.

Milian Boix, Manuel (1969), El fondo "Instrumenta Miscellánea” del Archivo Vaticano. Documentos referentes a España (853-1782), Roma.

Millares Carlo, Agustín (1943), Documentos del Archivo General de la villa de Madrid. Segunda serie, vol. II, Madrid.

Mitre Fernández, Emilio (1995), "La nobleza castellana en la Baja Edad Media: líneas maestras de formación y promoción”, Las instituciones castellano-leonesas y portuguesas antes del Tratado de Tordesillas. Actas de las Jornadas celebradas en Zamora (28 y 29 de noviembre de 1994), Luis Suárez Fernández y José Ignacio Gutiérrez Nieto (Coordinadores), Valladolid, pp. 121-130.

Monfar y Sors, Diego (1853), Historia de los Condes de Urgel, vol. X de la Colección de Documentos Inéditos del Archivo General de la Corona de Aragón. Ed. Próspero Bofarull, Barcelona.

Monreal y Cía, Gregorio (1975), Las instituciones públicas del Señorío de Vizcaya (hasta el siglo XVIII), Bilbao.

Monsalvo Antón, José María (1990), "La sociedad política en los concejos castellanos de la Meseta durante la época del regimiento medieval. La distribución social del poder", Concejos y ciudades en la Edad Media hispánica, León, pp. 358-413.

Monsalvo Antón, José María (1997), "Las dos escalas de la señorialización nobiliaria al sur del Duero: concejos de villa y tierra frente a la señorialización "menor". (Estudio a partir de casos del sector occidental: señoríos abulenses y salmantinos)", Revista d'Historia Medieval, 8, pp. 275-335.

Monsalvo Antón, José María (2001), "Usurpaciones de comunales: conflicto social y disputa legal en Ávila y su Tierra durante la Baja Edad Media", Historia Agraria, 24, pp. 89-122.

Monsalvo Antón, José María (2002), “Espacios de pastoreo de la Tierra de Ávila. Algunas consideraciones sobre tipos y usos de los paisajes ganaderos bajomedievales", Cuadernos Abulenses, 31, pp. 139-196.

Monsalvo Antón, José María (2008), "En torno a la cultura contractual de las élites urbanas: pactos y compromisos políticos (linajes y bandos de Salamanca, Ciudad Rodrigo y Alba de Tormes)", El contrato político en la Corona de Castilla. Cultura y sociedad políticas entre los siglos X al XVI, François Foronda y Ana Isabel Carrasco Manchado (Directores), Madrid, pp. 159-209. 
Monsalvo Antón, José María (2009), "Luchas de bandos en Ciudad Rodrigo durante la época Trastámara", Castilla y el mundo feudal. Homenaje al profesor Julio Valdeón, Mª . I. del Val, P. Martínez Sopena (dirs.), vol. III, Valladolid, pp. 201-214.

Monsalvo Antón, José María (2010), Comunalismo concejil abulense. Paisajes agrarios, conflictos y percepciones del espacio rural en la Tierra de Ávila y otros concejos medievales, Ávila.

Montoya, Jesús (1988), "Los maestres y encomiendas de la Orden de Santiago, su contribución en dinero y lanzas. (Colection Chiflet, Bibilioteca Municipal de Besançon)", Anuario de Estudios Medievales, 18, pp. 525-536.

Moreta Velayos, Salustiano (1978), Malhechores-Feudales. Violencia, antagonismos y alianzas de clases en Castilla, siglos XIII-XIV, Madrid.

Mota Arévalo, Horacio (1969), "Las órdenes militares en Extremadura", Revista de Estudios Extremeños, XXV, pp. 423-446.

Mugueta Moreno, Íñigo (2000), “Acciones bélicas en Navarra: la frontera de los malhechores (1321-1335)", Príncipe de Viana, año LXI, 219, pp. 49-78.

Munuera y Abadía, José María (2000), Apuntes para la historia de Totana y Aledo, Edición de María Martínez Martínez, Murcia.

Nieto Cumplido, Manuel (1982), "Luchas nobiliarias y movimientos populares en Córdoba a fines del siglo XIV", 3 Estudios de Historia Medieval Andaluza, Córdoba, pp. 11-65.

O'Callaghan, Joseph F. (1996), "Las definiciones de la Orden de Calatrava, 13831418", En la España Medieval, 19, pp. 99-124.

Orella Unzué, José Luis (1985), "La hermandad de frontera entre el Reino de Navarra y la provincia de Guipúzcoa. Siglos XIV-XV)", Príncipe de Viana, 175 año XLVI, pp. 463-491.

Orellana González, Cristóbal (2015), "Registro cronológicio de los registros capitulares de Jerez de la Frontera, 1409-1430", Revista de Historia de Jerez, 15, pp. 83-156.

Ortega Cervigón, José Ignacio (2006), La acción política y la proyección señorial de la nobleza territorial en el Obispado de Cuenca durante la Baja Edad Media, Tesis doctoral inédita, Universidad Complutense, Madrid.

Ortiz Real, Javier (1985), Cantabria en el siglo XV. Aproximación al estudio de los conflictos sociales, Santander.

Pangusión Cigales, Ernesto (2015), "La batalla de los Cuatro Juanes. Narración, localización y aportaciones a la caminería medieval del campo de Matrera”, $A$ los pies de Matrera (Villamartín, Cádiz) un estudio arqueológico del oriente de Šidūna, Eds. José María Gutiérrez López y Virgilio Martínez Enamorado, Villamartín, pp. 587-622.

Pardo Rodríguez, María Luisa (2000), “La escribanía mayor del Concejo de Sevilla en la Edad Media", La Diplomatique urbaine en Europe au Moyen Âge, Lovaina, pp. 357-381. 
Pareja Delgado, María Josefa (1987), "La conflictividad social en Baeza y Úbeda durante la Baja Edad Media”, V Congreso de Profesores Investigadores. Hespérides, Sevilla, pp. 127-137.

Pareja Delgado, María Josefa (1988), Baeza y Úbeda en la Baja Edad Media, Granada.

Peinado Santaella, Rafael Gerardo (1991), "La renta señorial en las Órdenes Militares de la Corona de Castilla durante la Baja Edad Media”, Historia. Instituciones. Documentos, 18, pp. 403-424.

Pérez Bustamante y González de la Vega, Rogelio (1976), El gobierno y la administración de los Reinos de la Corona de Castilla (1230-1447), vol. II, Madrid.

Pérez de Guzmán, Fernán (1953), Crónica del serenísimo príncipe don Juan, segundo rey deste nombre en Castilla y León, escrita por el noble y muy prudente caballero Fernán Pérez de Guzmán, Señor de Batres, del su Consejo, Biblioteca de Autores Españoles, Colección ordenada por don Cayetano Rosell, vol. LXVIII, t. II, Madrid.

Pino García, José Luis del (1991), Extremadura en las luchas políticas del siglo $X V$, Badajoz.

Porras Arboledas, Pedro A. (1981), Los Señoríos de la Orden de Santiago en su Provincia de Castilla (Siglo XV), Madrid, 2 vols.

Porras Arboledas, Pedro A. (1988), "Los bandos señoriales en la ciudad de Jaén en los siglos XIV y XV", Senda de los Huertos, 9, pp. 29-39.

Porras Arboledas, Pedro A. (1990), "La aristocracia urbana en Jaén bajo los Trastámara: los Mendoza y los Berrio”, En la España Medieval, 13, pp. 271-301.

Porras Arboledas, Pedro A. (1997), "La ciudad de Jaén (1246-1525). Avatares políticos e institucionales de una ciudad fronteriza", En la España Medieval, 20, pp. 195-218.

Portilla Vitoria, Micaela J. (1978), Torres y Casas fuertes en Álava, vol. I, Vitoria.

Quintanilla Raso, María Concepción (1982), "Estructuras sociales y familiares y papel político de la nobleza cordobesa (siglos XIV-XV)", En la España Medieval, 3, pp. 331-352.

Rades y Andrada, Francisco de (1980), Crónica de las tres Órdenes de Santiago, Calatrava y Alcántara, Barcelona, (Facsímil de la de Toledo, 1572).

Rodríguez Amaya, Esteban (1950), "Don Lorenzo Suárez de Figueroa, Maestre de Santiago", Revista de Estudios Extremeños, V, pp. 241-302.

Rodríguez Blanco, Daniel (1985a), La Orden de Santiago en Extremadura en la Baja Edad Media (Siglos XIV y XV), Badajoz.

Rodríguez Blanco, Daniel (1985b), "La organización institucional de la Orden de Santiago en la Edad Media", Historia. Instituciones. Documentos, 12, pp. 176-192.

Rodríguez Blanco, Daniel (1991), "Los concejos de las Órdenes Militares en la Baja Edad Media. Organización y Relaciones de poder", Historia. Instituciones. Documentos, 18, pp. 425-443.

Rodríguez Llopis, Miguel (1982), Conflictos fronterizos y dependencia señorial: La encomienda de Yeste y Taibilla (siglos XIII-XV), Albacete. 
Rodríguez Llopis, Miguel (1986), Señoríos y feudalismo en el reino de Murcia. Los dominios de la Orden de Santiago entre 1440 y 1515, Murcia.

Rodríguez Molina, José (1974-1975), "Las Órdenes Militares de Calatrava y Santiago en el Alto Guadalquivir (Siglos XIII-XV)", Cuadernos de Estudios Medievales, II-III, pp. 74-81.

Rodríguez Molina, José (1991), "Bandos en las ciudades del Alto Guadalquivir, siglos XV-XVI. Repercusiones”, Actas del VI Coloquio Internacional de Historia Medieval Andaluza. Las ciudades andaluzas (siglos XIII-XV), Málaga, pp. 537-549.

Román de Cuenca, Juan (2012), El libro del Alcázar. De la toma de Jerez a la conquista de Gibraltar. Siglos XIII-XV, Introducción, edición e índices de Juan Abellán Pérez, Jerez de la Frontera.

Ruano y Prieto, Fernando (1904), "El Condestable D. Ruy López Dávalos, primer Duque de Arjona", Revista de Archivos, Bibliotecas y Museos, $3^{\mathrm{a}}$ época, año VIII, XI julio-diciembre $n^{\circ}$ III, pp. 398-408.

Rucquoi, Adeline (1984), "Noblesse urbaine en Castille (s. XIII-XV)", Actes du 106 Congrès National des Sociétés Savantes, Paris.

Ruiz Pilares, Enrique (2010-2012), "La formación de la oligarquía jerezana y la patrimonialización de los oficios concejiles (siglos XIII al XV)", Revista de Historia de Jerez, 16-17, pp. 67-77. Consultado en línea 14 abril 2018.

Sáez, Emilio (1946), "Privilegio de la Orden de Santiago a Caravaca", Hispania, VI, pp. 123-137.

Salazar Fernández, Luis Miguel (1993), Colección diplomática del concejo de Segura, San Sebastián.

Salazar y Castro, Luis de (1949), Los Comendadores de la Orden de Santiago, Madrid.

Sánchez Benito, José María (1990), Colección de ducumentos de la Santa Hermandad (1300-1500), Toledo.

Sánchez Saus, Rafael (1991), Linajes sevillanos medievales, Sevilla.

Sánchez Saus, Rafael (1996), Linajes medievales de Jerez de la Frontera, vols. I y II, Sevilla.

Sánchez Saus, Rafael (2005), "Los orígenes de la aristocracia sevillana del siglo XV" y "La nobleza sevillana medieval. Orígenes, evolución y carácter", en $L a$ nobleza andaluza en la Edad Media, Granada, pp. 15-44 y 45-68.

Sánchez Saus, Rafael (2009), Las élites políticas bajo los Trastámara. Poder y sociedad en la Sevilla del siglo XIV, Sevilla.

Sánchez Saus, Rafael (2012), "De élite funcional a nobleza de sangre. Las oligarquías urbanas en la Baja Edad Media”, Del municipio a la corte. La renovación de las élites romanas, Estudios reunidos y presentados por Antonio F. Caballos Rufino, Sevilla, pp. 363-371.

Solano Ruiz, Enma (1978), La Orden de Calatrava en el siglo XV. Los señoríos castellanos de la Orden al fin de la Edad Media, 1978.

Suárez Fernández, Luis (1951), "Evolución histórica de las Hermandades castellanas", Cuadernos de Historia de España, XVI, pp. 5-78. 
Suárez Fernández, Luis (1960), Castilla, el Cisma y la Crisis conciliar (13781440), Madrid.

Tapia Garrido, José A. (1991), Historia general de Almería y su provincia. Almería musulmana (1172-1492), vol. IV, Almería.

Tomás y Valiente, Francisco (1970), “Origen medieval de la patrimonialización y la enajenación de los oficos públicos en Castilla”, Actas del I Symposium de Historia de la Administración, Madrid, pp. 123-159.

Torres Fontes, Juan (1961), "Notas sobre fieles del rastro y alfaqueques murcianos", Miscelánea de Estudios Árabes y Hebraicos, X, pp. 89-105.

Torres Fontes, Juan (1963-1964), "Los hidalgos murcianos en el siglo XV", Anales de la Universidad de Murcia, XXIII, pp. 5-22.

Torres Fontes, Juan (1965-1966), "Los castillos santiaguistas del reino de Murcia en el siglo XV", Anales de la Universidad de Murcia, XXIV, pp. 325-348.

Torres Fontes, Juan (1982a), Documentos para la historia medieval de Cehegín, Murcia.

Torres Fontes, Juan (1982b), "Puerto de La Losilla, portazgo, torre y arancel", Miscelánea Medieval Murciana, IX, pp. 57-85.

Torres González, T. (1988), Torre de Don Miguel. Historia de una villa rural de la Baja Edad Media, Cáceres.

Torres y Tapia, Alonso (1999), Crónica de la Orden de Alcántara, vol. II, MéridaTrujillo-Alcántara, (Edición facsímil de la editio princeps de 1763).

Urosa Sánchez, Jorge (1998), Política, seguridad y orden público en la Castilla de los Reyes Católicos, Madrid.

Vadaurrázaga e Inchausti, José Luis (1975), Nobiliario alavés de Fray Juan de Victoria siglo XVI, en Diccionario onomástico y heráldico vasco, por Jaime de Querexeta, vol. VI, Bilbao.

Val Valdivieso, María Isabel del (1985), "La sociedad urbana del Señorío de Vizcaya en la Baja Edad Media”, En la España Medieval. La ciudad hispánica durante los siglos XIII al XVI, 6, pp. 317-335.

Val Valdivieso, María Isabel del (1989), "Universidad y luchas urbanas en la Castilla bajomedieval", Mayurqa. Homenatge a Álvaro Santamaría, vol. I, 22, pp. 213-227.

Vilaplana, María Asunción (1974), “Un ajuste de cuentas del alcabalero mayor de Sevilla Pedro Ortiz (1420)", Historia. Instituciones. Documentos, I, pp. 417502.

Villar y Macías, Manuel (1887), Historia de Salamanca, vol. II, Salamanca.

Viña Brito, Ana (1991), Morón y Osuna en la Baja Edad Media, Sevilla.

Zudaire, Eulogio (1972), "Los Reyes Católicos rubrican la Concordia de Azcoitia", Boletín de la Real Academia de la Historia, CLXIX, pp. 359-403.

Zumalde, Ignacio (1957), Historia de Oñate, San Sebastián.

Zurita, Jerónimo $\left(1980^{2}\right)$, Anales de la Corona de Aragón, Edición de Ángel Canellas López, vol. V, Zaragoza. 